UC-NRLF

Hint

B 3272339
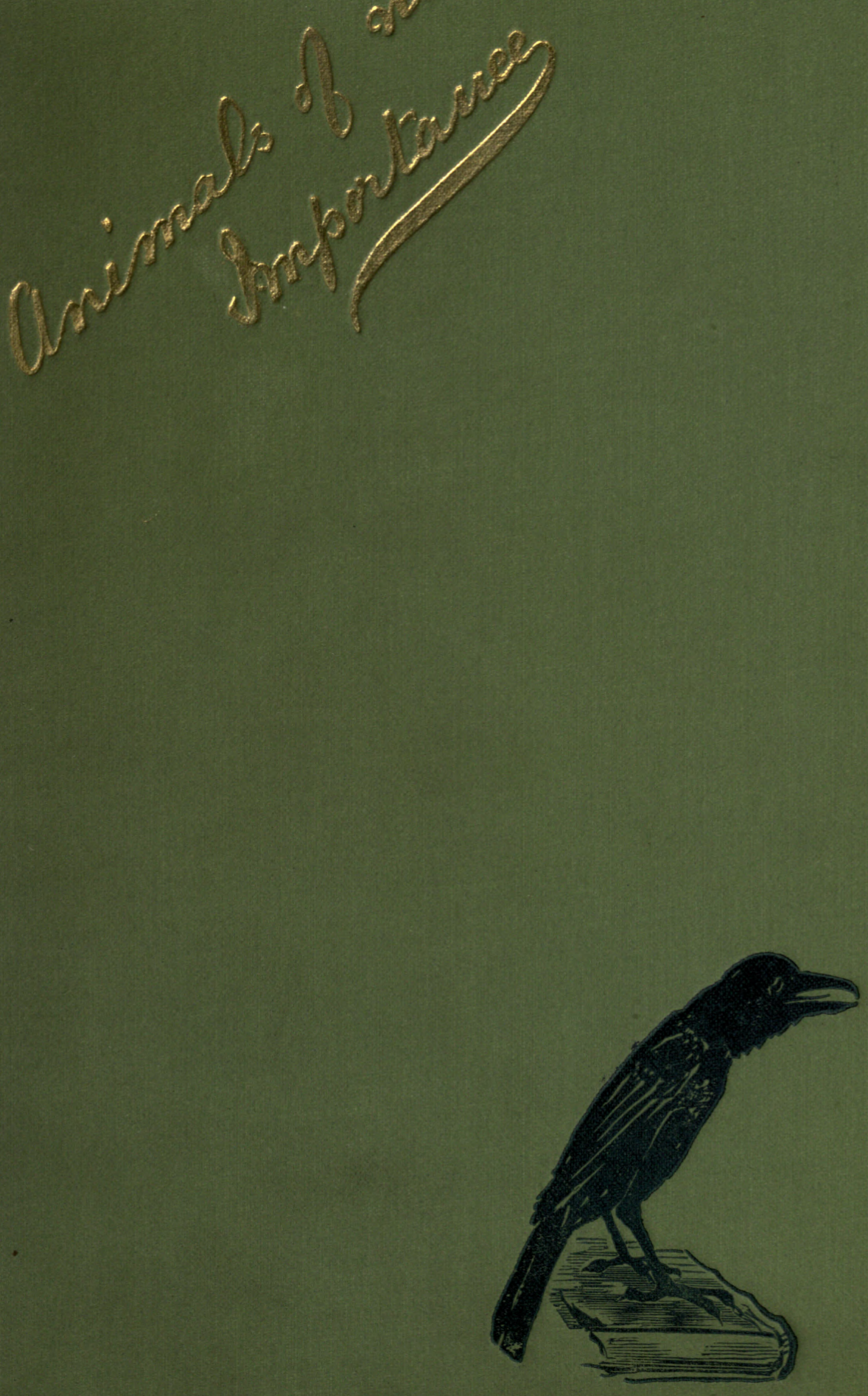

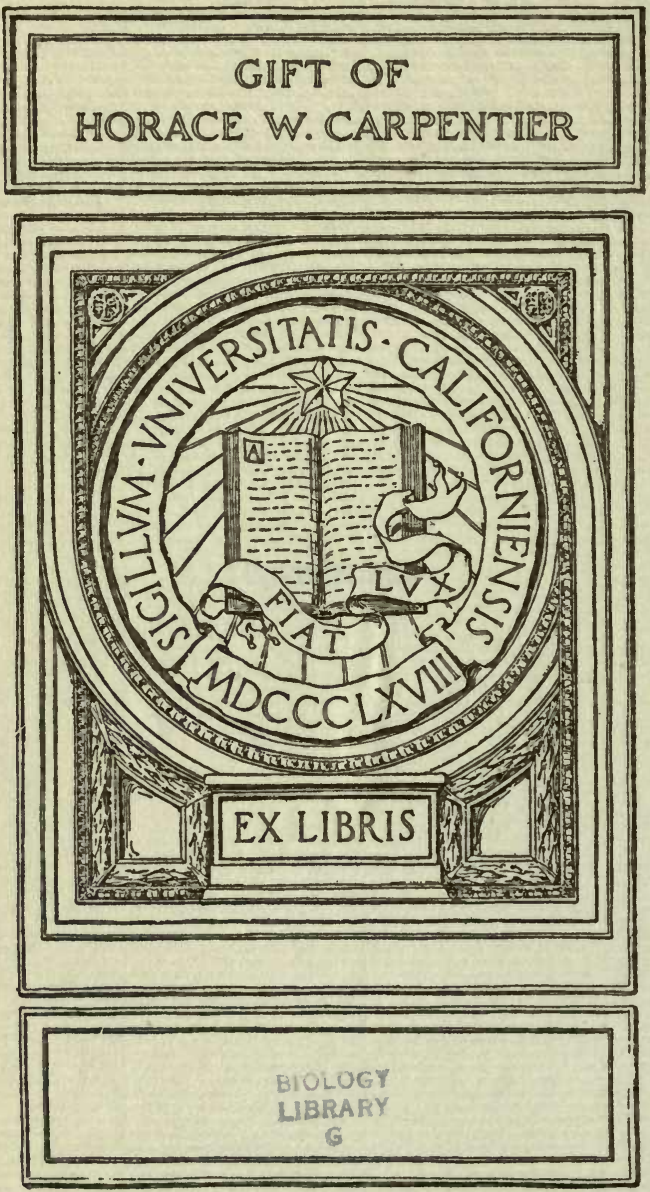
$\operatorname{lom}_{c}^{l}$

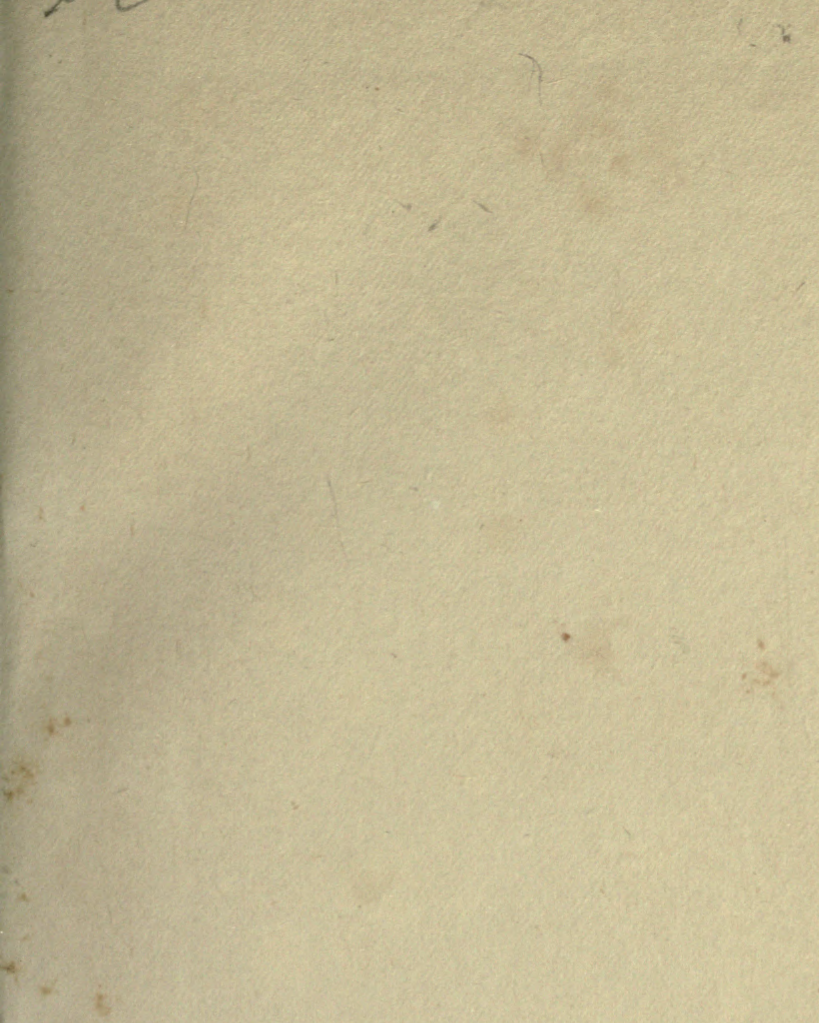







\title{
ANIMALS OF NO IMPORTANCE.
}

\author{
BY \\ D. DEWAR.
}

CALCUTTA AND SIMLA :

THACKER, SPINK \& Co.

LONDON :

W. THACKER \& Co., 2, CREED LANE, E. C. 


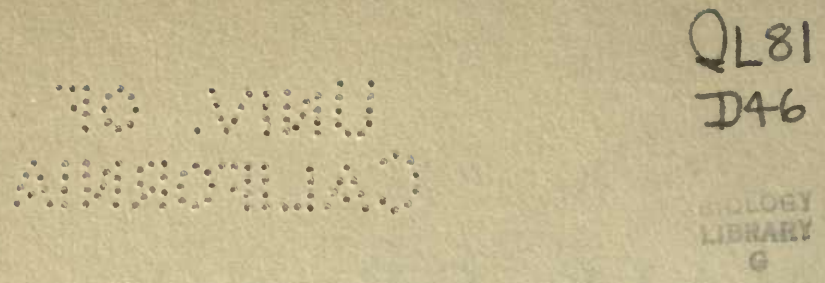

\section{QRRTEWTIE?}

PRINTED AT THE

"TIMES OF INDIA" PRESS BOMBAY 


\section{CONTENTS.}

PAGE

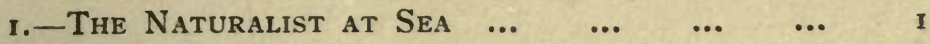

2. - A MUCh-AbUSEd Bird

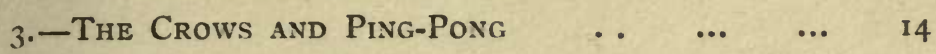

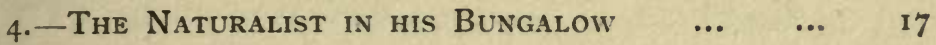

5.-The Naturalist in his Verandah $\quad \ldots \quad \ldots e r$

6. - Тhe Cuckoo $\ldots . \quad \ldots \quad$...

7.-An Eight-legged Ishmaelite $\quad \ldots \quad$...

8._INSECt INVADERS

9.-Mediaval Notions of Indian Natural. History. 49

iO.-A Misnamed Bird $\ldots$..

I I.—Dutch Nightingales... $\quad \ldots \quad$.

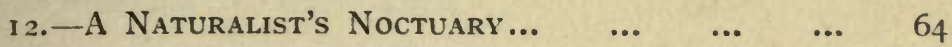

13. - The Malaria Middleman $\ldots$...

14. - Mammals of The Air $\quad \ldots \quad$...

15.-The King-Crow $\quad \ldots \quad$...

16. -The Hone of the Swift $\ldots$.

17.-Musca Diabolica

18.-HOBBLEDEHOYS $\quad$..

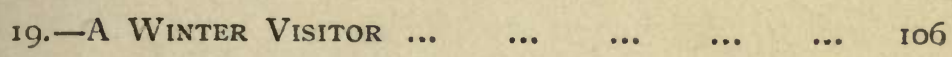

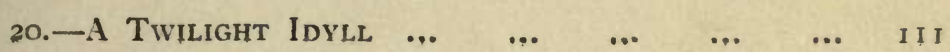



THESE sketches first appeared in The Times of India, with the exception of "Mediæval Notions of Indian Natural History," which made its débôt in The Indian Daily Telegraph.

It is owing to the courtesy of the Editors of the above-named newspapers that the essays have been reproduced in book form. 


\section{DEDICATE THIS BOOK TO CORVUS SPLENDENS; ESQUIRE,}

THE GREY-NECKED CROW,

most clever and cunning of birds, who disturbs my morning slumbers, who converts into a play-ground the back of my unresisting mare, who devours my choicest fruit as it ripens on the tree, who steals every portable object upon which he can lay his clarus, but who, as a set-off to his misdeeds, has afforded me much amusement. 


\section{ANIMALS OF NO IMPORTANCE.}

I.

ERRATA.

PAGE LINE

51, 12, for Otesias's read Ctesias's.

54, 19, for dispute read disrepute.

$67, \quad 17$, for most read many.

69, 9, for Koel read Brain-fever Bird.

98, last, for fly read insect.

The tormer class inhabit the cold waters of the lowest depths where the pressure is enormous, and where eternal darkness prevails. These animals never come to the surface, so that the ordinary traveller cannot hope to see any of them.

As regards the fauna of the surface, the naturalist is more fortunate. But here again several causes militate against him. There are two classes of animals which live near the surface; those creatures which are powerful swimmers and are able to travel whither they will-these are sometimes 
I DEDICATE THIS BOOK TO CORVUS SPLENDENS; EsQUiRE, 


\section{ANIMALS OF NO IMPORTANCE.}

I.

THE NATURALIST AT SEA.

$\mathrm{I}^{\mathrm{T}}$ is the opinion of most people that during the voyage to and fro between England and India but little opportunity of pursuing his favourite study presents itself to the naturalist. This is, in a sense, true. For when we consider the extent to which the ocean teems with animal life, when we reflect that every wave that breaks against the ship's side contains hundreds of living organisms, we cannot but wonder that we, from the deck of the ship, do not see more of the inhabitants of the sea. A little consideration, however, will clear up the mystery. Animals that live in the ocean fall into two classes-deep-sea creatures and organisms which dwell near the surface.

The former class inhabit the cold waters of the lowest depths where the pressure is enormous, and where eternal darkness prevails. These animals never come to the surface, so that the ordinary traveller cannot hope to see any of them.

As regards the fauna of the surface, the naturalist is more fortunate. But here again several causes militate against him. There are two classes of animals which live near the surface; those creatures which are powerful swimmers and are able to travel whither they will-these are sometimes 
called the Nekton; and the smaller organisms whose natatory powers are but small, and which are at the mercy of the waves, being carried about hither and thither by wind and current. This group, which includes jelly-fish and small crustaceans, is often termed the Plankton. The Nekton are disturbed by the approach of the-ship and hurry away from it, and thus mostly elude the observer's gaze. Most of the Plankton, on the other hand, are so small as to be invisible to the naked eye; and the majority of them come to the surface only at night, descending some feet as soon as daylight approaches. The object of this daily migration is to enable these lowly organisms to make the most of the light. This habit of descending during the day allows them to search for food, both by day and by night. Were they to remain at the surface during the day, they would lose their only chance of obtaining food at a greater depth.

Of the remaining Plankton others are almost transparent, so that it is most difficult to see them when the sea is at all rough. But give him one of those heavenly days, so few and far between, such as March 6th, 1900, when the sea was as smooth as glass, and the naturalist desires nothing more. He has ample opportunity of studying marine life. But he must go right forward to the bow of the ship, where he can look down into the blue water as yet undisturbed by the rude contact of the fast-moving steamer. Magnificent jelly-fish may be seen in thousands, some almost perfectly transparent, others of a milky-white hue with pink patches. They float near the surface, moving most gracefully by the rhythmic contraction of their "bell " or "umbrella." There is no more beautiful sight in nature than the movement of a medusa. Dozens of other Plankton may be seen on such a day, creatures of diverse form and size, displaying the most beautiful tints : deep red, orange, pink, brown, yellow, and blue. In half an hour the writer noticed no fewer than eleven different genera of such organisms-Medusa Siphonophora, and Ctenophora. 
Many of these surface-floating forms are phosphorescent. Such are best seen at night. Upon some evenings all the water disturbed by the boat assumes the appearance of liquid phosphorus. This phenomenon is due to the fact that many of the minute organisms in the water are phosphorescent. The commonest light-emitting creature is a tiny animal called Noctiluca. It is invisible to the naked eye and is usually cherry-shaped. Sometimes, however, its form is more like that of a kidney. From the depressed side there projects a short whip-like process, termed the flagellum, by the lashing of which the creature slowly forces itself through the water.

We now come to the Nekton, animals that are powerful swimmers, such as fish, whales, sharks, dolphins, and porpoises. Sharks abound in the tropical seas, as the condition of some of the unfortunate "have-a-dive" boys amply testifies. These evil fish, however, do not readily show themselves, and the traveller cannot expect at the best to see more than a dark fin.

Whales, dolphins, and porpoises are mammals which have taken to an aquatic life. A whale is no more a fish than a dog is. It breathes by lungs, not by gills. The female suckles her young. It possesses no fins, but swims by means of its legs which have become modified into flappers. Since lungs form the breathing organ of the whale, it must continually come to the surface in order to breathe. Then it is that the presence of the monster becomes known. The "spouting" of whales is part of the breathing process. When the whale wishes to take in a fresh supply of air he comes to the surface, and just before he reaches it makes a violent expiratory effort. Thus much air is forced out of his nostril, which, passing through water, reaches the atmosphere as a jet of spray. It is an error to imagine that the whale ejects water from its nostril.

Porpoises are common objects in the Indian Ocean. Like whales, they are mammals. They are usually seen in swarms or "schools," which often accompany ships for 
considerable distances. As often as not the porpoises precede the ship, hence their object in accompanying it cannot be to catch stray particles of food. There appears, indeed, to be but one explanation of the phenomenon-the inquisitiveness of the porpoise. Curiosity is a common trait in animals. Take, for example, the oft-quoted cases of dogs and monkeys. There is but little doubt that the porpoise is naturally curious. A "school" sees a new and strange sight in the shape of a ship and turns aside to behold the wonder. No observer can fail to be impressed by the graceful movement of the porpoise and also by the great speed at which he travels through the water. For hours a porpoise will keep pace with a steamer, crossing and re-crossing her bows with the greatest impunity. Sometimes a school of porpoises advances in Indian file. In such a case, seen from a distance, they look like an enormous sea-serpent; each revolving porpoise appearing like a coil of the serpent's body. This is possibly the origin of the sea-serpent myth.

Flying-fish are very common objects in the Red Sea and Indian Ocean, constantly jumping out of water when disturbed by the approach of the ship. These creatures have greatly enlarged wing-like pectoral fins. The tail is also of considerable magnitude. Fins and tail are the organs which assist these animals in their flight. A flyingfish jumps out of the water to a height of usually from two to three feet, and describes a parabolic curve until it touches the water, when it flaps its fins vigorously and again rises and performs a similar, but generally shorter. curve. This process may be repeated several times before the fish finally disappears in the water. There is a considerable controversy raging on the question of the use of the fins to this fish in its flight. Some authorities declare that the fins act merely as a kind of parachute, enabling the creature to prolong its jump into the air. Others, however, assert that the animal flaps its fins while in the air, thus using them as a bird does its wings. 
The writer had exceptional opportunities of closely observing flying-fish in the Indian Ocean during most unusually calm weather. While describing the parabolic curve in the air the creature never moves its fins. It is only when it touches the water again that it gives several vigorous flaps with its fins until it attains sufficient impetus for another flight. Seen from a distance, these fish certainly do seem to flap their fins in the air. This, however, is probably an optical illusion caused by the reflection of the sunlight from the fins as the creature sways from side to side during its flight. Flying-fish do not appear to remain longer than seventy or eighty seconds out of water. They attain a considerable speed during their flight, probably between twenty and thirty miles an hour. In the daytime these fish fly away from the ship; at night they fly at it, and sometimes enter a porthole.

The Bonito is a large fish often seen in tropical seas. This creature is capable of taking enormous jumps out of the water. It is said to feed upon flying-fish and to catch them during their flight in the air.

Before leaving the subject of marine vertebrata, mention must be made of the turtles which are sometimes visible in great numbers floating in the Mediterranean near the shore. These organisms are especially abundant off the Coast of Greece. Their carapace acts as a most efficient float.

Insects are frequently blown out to sea by gales of wind, and occasionally fall on ships. In the Red Sea we passed through a flight of locusts, a great number of which fell upon board. As a rule, insects are not common at sea. There is, however, a small white moth that flits over the surface of the ocean. This insect is common in the Arabian Sea. How these moths get there is a mystery. Some people think that they are evolved from grubs on ships. Their number would, however, seem to preclude this theory.

Great variety of bird-life is not usually seen during the voyage from England. On the banks of the Suez Canal 
an Egyptian vulture may sometimes be espied, while the marshy lakes in that region contain a variety of bird-life; among other forms flamingoes are conspicuous. In the open sea one now and again comes across a flock of migratory birds. While in mid-ocean birds are few and far between; with the exception of a few gannets, the atmosphere appears almost devoid of bird-life.

- Near land gulls are numerous and follow the ship in considerable numbers. The movements of sea-gulls are extremely graceful. These beautiful creatures keep pace with the ship with ridiculous ease, now just skimming the water, now soaring high in the air; at one moment far behind the ship, at the next directly over head, flying round and round in circles. These birds seem able to fly for hours without tiring. A dozen flaps of the wing in a minute is more than sufficient to enable them to keep up with the boat, that is to say, to fly at the rate of about fifteen miles an hour. They are, however, able to attain a far greater velocity. It is difficult to estimate the greatest speed at which gulls can fly, for they probably rarely extend themselves. The writer's observations would seem to indicate that gulls have no difficulty in flying, for a short distance at least, at the rate of forty miles an hour. This would seem to coincide with the results of other observers. The flight of birds is a most interesting subject, and one upon which our knowledge is at present very incomplete. For purposes of flight birds fall into two classes-those with heavy bodies and short rounded wings, and those with light bodies and large wings. The former move their wings very rapidly, and fly for a short distance with great velocity. Thus, driven partridges are said to travel at a speed of sixty miles an hour. This class of birds cannot fly far, and are not usually found at sea. The gull and the gannet belong to the other class, their wings being long and their bodies light. They are able to accomplish long journeys, often at great speed. The motion of their wings is always slow. In one experiment a swallow flew 160 miles in ninety minutes, 
or at the rate of 106 miles per hour. Gulls may be able to attain such a speed, but under ordinary circumstances they never do so. The writer has spent many hours watching these birds, and never has their pace approached this rate. Forty miles an hour would appear to be their limit. But they are never pushed, so may be capable of yet greater speed. Could anyone devise some experiment, whereby the velocity of flying birds could be accurately gauged, he would be a benefactor to science.

Gulls, like vultures, have excellent sight. If pieces of bread be thrown into the water, the gulls will quickly seize them, but they will not take the slightest notice of paperballs similarly thrown to them. They appear to fly with eyes fixed upon the water. If a piece of bread be thrown from a moving ship into the sea the gulls which are ahead of the bread when it reaches the water will make no effort to pick it up, apparently not having seen it. On the other hand, one of the gulls behind the bread when it drops into the water will never fail to secure it.

The sea-gull is, perhaps, the most fascinating of all the interesting studies that present themselves to the naturalist during the voyage to England.

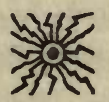




\section{II.}

\section{A MUCH-ABUSED BIRD.}

$A^{T}$ all times and in all ages the crow appears to have incurred the displeasure of man. At any rate writers seem with one accord to have combined to abuse that sagacious bird. And one species of crow-the common Indian one, Corvus splendens-has come in for more vilification than all the rest of the crow tribe put together. Even the staid Jerdon " often regrets that such an inappropriate specific name should have been applied to this species, for it tends to bring into ridicule, among the unscientific, the system of nomenclature." Hodgson, too, would have none of this waggish name; he would call a spade a spade, and the Indian crow Corous impudicus. According to Phil. Robinson, "crows are indubitably the connecting link between devils Class 3, inventors of all mischief, Prince Belial at their head; and Class 4 malicious devils, under Prince Asmodeus." "Eha" has never been able to discover any shred of grace about a crow. "Even a consistent career of crime," writes he, " must be less demoralising than the aimless vagabondage by which it maintains itself." From quotations such as these it is evident that the crow will bear a little white-washing. The strong point in the crow's case is that he might have been worse. For sheer wickedness the crow is not in the same street as the cuckoo. Compared with the villainy of the latter the crimes of the former are tame affairs. For what are they? Profanity, theft, greed and general "cussedness" fairly exhaust the list. Let us in the true scientific spirit consider these corvine sins in order. For the profanity of the crow I can vouchsafe. Only last week I heard one swear. It happened in this wise. I was walking along the dusty cart track, 
which we in our simplicity call the Mall of the station, when I came upon a crow making tremendous efforts to swallow a piece of paper. From the moment he caught sight of me he, crow-like, kept one eye on me. When I approached nearer than he liked he hopped off, and happened to land on the upturned end of a crooked twig. The other end struck him full in the face. The look which that crow bestowed on the offending branch was worth going miles to see. As to his language, I could not repeat it, for, in the first place, I did not understand it, and, secondly, if I had understood it, I fear the Editor of this paper would have refused to print it for fear of shocking any bargees into whose hands it might happen to fall.

The crow is certainly greedy, but then so are all animals and many human beings. That being so, it is unfair to lay this sin to the charge of the crow. The crow is, further, in our eyes a thief; he will steal anything he can lay his beak upon, from one's chota hazri to one's stamps, but then every animal who has the pluck to do so will steal them, provided, of course, the said animal has use for these articles. In extenuation of the crow we must remember that the sagacious bird, in common with all thinking animals, indubitably shares the belief that the chief end of man is to make himself generally useful to the other animals. This being the case, it follows that men build verandahs to their bungalows for the delectation of crows, and prepare food for them to eat. Theft is apparently not an offence that comes within the animal penal code, and if it did, theft, where man was the victim, would come among the exceptions at the beginning of the volume, for where man is concerned animals are without doubt doli incapax. Thus the first three of the alleged sins of the crow are easily disposed of. However, the matter is different with regard to the fourth-the general "cussedness" of the crow. This is his prevailing sin and one which is quite inexcusable. No right-thinking animal could possibly believe that man was created especially for it to tease. The crow acts as 
though it did believe this. When the weary Anglo-Indian determines to spend an "Europe morning" all the crows in the neighbourhood manage to find this out. How they accomplish this I am unable to say for certain, but I strongly suspect that a douceur to the bearer does the trick. Whether this is so or not it matters little; what does matter is that the crows find out, and take up a position in the verandah at dawn and "squawk" in concert until they awaken the sahib, and make him so irate that further sleep is out of the question. Have we not all had frequent and painful experience of the untimely loquacity of the crow? Why then dilate further upon this painful subject? I do not attempt to explain away the general "cussedness" of the crow. The only apology that I have to offer is that it is the result of the great intelligence of the bird. Now it is a sad truth that intelligence among animals always shows itself in the form of wickedness. Possibly the monkey, cat, and cuckoo are the most intelligent of the animals. Can one conceive of a more wicked trio? It is a hard saying, but nevertheless a true one, that if you want to behold a perfectly good animal, that injures nothing, you must descend to the oyster; and indeed even this inoffensive molluse sometimes causes illness to those who eat him.

If crows are bold bad birds they, unlike the cuckoo, who is far more wicked, often get punished for their evil deeds. There is one unfortunate crow in our station, around the neck of whom some wag has tied a little bell, such as one often sees attached to a lapdog. Thus this crow is forced for his sins to go through life like the lady who rode to Banbury Cross with " music wherever she goes." The tinkling of the bell as the crow flies overhead causes some surprise to those not conversant of the facts of the case; they are apt to think that they have discovered a new species of bird. The lot of this crow is a happy one as compared with that of the member of the tribe who is obliged to carry about with him a Wills' cigarette tin, through the bottom of which his head has been thrust by some soldier ! 
The characteristic of the crow is his adaptability. The majority of birds and beasts are unable to adapt themselves to any marked change in their environment. Not so the crow. He is to all the other birds what the Yankee is to the rest of mankind. He can make himself at home anywhere. If ever a bold adventurer reaches the North Pole he may be tolerably certain of finding a colony of crows there. Perhaps the most striking instance of the adaptability of the crow is furnished by the immortal Calcutta bird who built her nest with the wires of sodawater bottles. Even as I write there are before my eyes eight crows who have discovered that a bath put out into the garden by the artistic bheestie, makes an excellent drinking trough.

The crow offers further proofs of his versatility in the divers ways in which he obtains his food. The common Indian crow was probably originally almost purely a carrion feeder. Although they to this day do eat carrion they have discovered so many other kinds of food that it is probable that some crows go through life without tasting what was once their usual diet. Nowadays the commonest food of the crow is the fragments cast away by men-white and coloured. The crow is not hampered by caste prejudices; he revels in the meat left by the sweeper equally with the rice that has fallen from the Brahman's table. More acceptable than either are the leavings which are thrown away by the European's servants. The crows of the neighbourhood soon learn the hour at which these are pitched out, and make a point of being present. Crows, indeed, are always on the look out for a human being feeding, for they know that when he has finished there will always be left some fragments for them. Hence the smoke of a camp fire will invariably attract some crows, for they have learned to associate a fire with man's feeding. Insects, too, do not come amiss to crows. When the white ants swarm the clever birds may be seen actively engaged in catching them on the wing; and a flight of locusts is quite an 
occasion for the crows. The ticks which irritate cattle form another favourite dish for the crow, and as often as not one is to be seen perched on the back of an Indian cow. Crows will, faute de mieux, dig out grubs from the earth, and Jerdon states that "a few, in the vicinity of large rivers or creeks, follow vessels and hunt with the gulls and terns." Crows will further eat fruit in much the same way as green parrots do. Thus it is not to be wondered at that crows are ubiquitous. They can pick up a living anywhere; hence are to be found all over India.from the Himalayas to Ceylon.

There are so many points of interest connected with corvus splendens that it is not possible to mention them all in one article, and it is not an easy matter to know what to omit. Perhaps the most notable feature of the crow is his colour. Most birds and beasts are clothed so as to be inconspicuous in their natural haunts. Not so the crow. $\mathrm{He}$, whether flying or at rest, is about as conspicuous as he could well be. The reason of this is that the crow has no enemies to fear. Not a bird or beast will touch him dead or alive. Even the jackal draws the line at the crow. This I proved by shooting a crow about a hundred yards from the camp in a place where jackals swarmed. Three days afterwards when the camp was struck, there was the dead crow lying untouched just as it had fallen, an ugly mass of blackness. Nor is the crow a predacious bird, so that it has not to try to conceal itself from its prey. It has therefore no reason for making itself inconspicuous ; on the other hand, it is profitable for it to be as showy as possible in order that predacious birds may not mistake it for some edible species. Thus the crow is black and flies slowly and casually, as much as to say to the rest of the world "I am not good eating, so leave me alone."

In conclusion, a few remarks on the intelligence of the crow will not be out of place. There is in our station an enthusiastic gardener who regards all birds in the light of deadly enemies, and upon them he carries on unceasing 
warfare with a small air-gun. It is needless to say that never a crow is to be seen in his garden. They abound in every other part of the station, but they taboo a circular area, of which the diameter is about 150 yards, with this garden as a centre. Outside the 75 yards radius there is. to be seen a regular cordon of crows. They very rarely venture within the circle, and if one does make so bold it takes to its wings the instant anyone raises so much as a stick. Not so the crows outside the radius; they refuse to budge even when the air-gun is fired at them ; they sit through it all and caw derisively.

The amusements of crows are as diverse as their food. Undoubtedly their favourite pastime consists in cawing and cackling to one another to the annoyance of man. After this their most popular recreation is teasing other birds. This they do by swooping down on some unsuspecting bird which is probably half asleep, and thus causing it great alarm. If one may judge from the loud caws of the crows, they are greatly delighted at the fright of the victim of their little joke. Sliding down a cow's tail is another form of amusement in which I have seen the crows of our station indulge. A crow having finished his search for ticks in the skin of the cow, hops along the latter's back until he reaches the tail, which he then grips loosely with his claws, and slides slowly down in a way similar to that in which a small boy likes to slip down the balustrade of the staircase. As soon as he reaches the knobby portion at the extremity of the cow's tail, the crow takes to his wings and alights on the quadruped's back, and again proceeds to repeat the game. The cow does not appear to resent in the least the strange use to which the crows put her tail ; perhaps she allows them the use of it as a quid pro quo for the service they have performed in ridding her of the ticks which cause her so much annoyance. 


\section{III.}

\section{THE CROWS AND PING-PONG.}

\section{A CHAPTER IN TWENTIETH CENTURY NATURAL HISTORY.}

GREAT is the indignation of the crows of our station. $G$ And the cause of it all is that new-fangled game, that sign of twentieth century degeneracy, ping-pong. Utterly regardless of the fact that it was the Sabbath, and that a high Episcopal dignitary was staying in the station, it was ordained that the "final" of the local ping-pong tournament should be played off last Sunday. One of the competitors was a retired colonel of three-score years and ten, but his eye is not dim, nor is his natural force abated. He lost, but not without making a plucky fight of it. $\mathrm{He}$ attributes his defeat to the fact that an unsound ball was used at a critical juncture. The colonel acted up to his belief, and wrought vengeance upon the ball by sending it forth into space. The ball, although unsound, obeyed the laws of gravitation; it fell on a grassy plot. Presently a vigilant crow espied that ball, and, taking it for an egg, swooped down upon it, seized it in its powerful beak, and bore it off in triumph. Of course it was very foolish of the crow to mistake a ping-pong ball for an egg; for, granted that he was not a society bird, acquainted with the mysteries of ping-pong, the weight of the ball should have sufficed to convey to his corvine mind the fact that it could not contain a very substantial breakfast. But crows, although the cleverest of birds, are really very silly, if judged by human standards. They have not the wit to discover when a koel has dropped an egg into the nest, nor have 
they the sense to distinguish the interloper, when it is hatched, from one of their own kind.

Having secured its prize, the worthy crow took up a commanding position on the branch of a bamboo tree. After a little "prospecting" he caught sight of a small stone post, which appeared to be admirably adapted to his purpose. To this he flew, and dropping the ball, pecked at it to break it. Instead of breaking, the ball hopped on to the ground; the crow retrieved it and again had a peck at it, with the same result. Having repeated the process half a dozen times the crow grew thoughtful. Never before had he come across such an obstinate egg. He then decided to tackle it upon the ground; here he met with no better success. He next flew to a neighbouring tree, and from that altitude contemplated the ball, which he had left lying on the ground. A happy thought suddenly seized him. He took up the egg in his beak, and flew with it to a branch some six feet above the ground, and let it fall. It survived the shock intact.

This was too much for another crow that had been attentively watching the first bird. Said he to himself : "If that juggins can't break the egg, there is nothing left but for me to show him how to do it." Having delivered himself of these sentiments he made a swoop at the ball, snapped at it as he flew over, but since the first crow was in hot pursuit he missed it. Then followed a long contest between the second bird and the rightful owner. Every time the former attempted to capture the egg, the latter flew after him and tried to peck him. After a little both birds came to rest on different trees within full view of the ball, each with his back towards the other. Crows are not straightforward birds. They live chiefly by deceit. Each wanted the other to think that he had forgotten all about the bone of contention. After the struggle had continued some twenty minutes, the first bird was seized with a sudden fit of generosity, and decided to let his rival have an innings. The latter's score was no larger than that of the first crow. 
The result of all his efforts was simply a duck's egg-I mean a ping-pong ball. In vain he pecked at the ball, which bounded away at each peck; in vain he jumped upon it. He was clearly losing his temper when a third crow arrived on the scene, and, little knowing what was in store for him, gaily tackled the egg, which the second crow gave up to him in the most self-denying manner. Before he had quite exhausted his energy two more crows arrived and forthwith attacked the ball. The other three crows remained placidly looking on from a neighbouring tree.

After a time the two new-comers who had taken alternate pecks at the celluloid sphere grew "shirty," and leaving it in disgust, they joined the other three birds in the tree, and the whole five cawed in unison, in a manner betraying the most unspeakable disgust. The caws to which they gave vent were identical in tone with those which they emit when they are deceived by an eclipse of the sun. It grows dark, and all the crows of the vicinity, as is their wont at eventide, come to roost on the accustomed tree. Just as they have comfortably settled themselves for the night, and before they have enjoyed a wink of sleep, the sun comes out again. This is too much for the feelings of the crows. Never before has such a trick as this been played upon them, so their righteous indignation is correspondingly great. In exactly the same manner did those five crows caw as they surveyed that ping-pong ball.

Most of the crows of the neighbourhood have come to know that ping-pong ball. Whether they now recognise its true nature I know not, but this I do know, that they have left it in a most conspicuous place; and one or two of them are usually hanging around, waiting on the chance of seeing some unsophisticated crow go up to the ball and try to break it. They then begin to look interested, and encourage him in his futile efforts by loud caws of derision. 


\section{IV.}

\section{THE NATURALIST IN HIS BUNGALOW.}

THE hot weather is upon us. The time is at hand when the dweller in the plains will become a daily prisoner in his bungalow. The season approaches when men will cry aloud for the mild sunshine of the hills or the cold mists of England. Not least among these complainers will be the naturalist, whom the hot weather debars to a great extent from his favourite pursuit. Right earnestly will he long for the time when he will be able once again to study Nature in comfort. But why cry out for the unattainable? Rather let us make the best of what we have. Even within the narrow confines of the darkened bungalow Nature may be studied. For I am not the only occupier of my home. I am but one among many. Living behind pictures during the day are two nimble lizards, which come out at eventide and rove up and down the walls in search of prey. One lizard has lost his tail, having probably left it in the hands of a would-be captor. It is, however, not a very serious loss, as it can be replaced. The new tail is just beginning to show. The absence of his tail does not appear to impede him, for he stalks his prey with incomparable craft and agility; darting now here, now there, and never failing to secure the hapless insect. There would seem to be a kind of etiquette in lizard society, for never do both my lizards hunt together. No sooner is the lamp lit and hung upon the wall than one appears, but one only. The energies of one lizard more than suffice for the scouring of the lit-up hunting ground, so one stands down, while the other ruthlessly 
devours hundreds of unfortunate insects. But we cannot afford to sympathise with the insects, for each one killed means one tormentor the less. Cold, timid, little reptile, what a debt of gratitude we Anglo-Indians owe you ! But for your efforts who can tell what our torments would be?

There are in my bungalow other beasts of prey, fierce and more voracious than any of the denizens of the jungle. One of these lives on the under side of a wicker table. There the spider spins her web. No one can have failed to notice the large abdomen of the spider : this contains the "silk" glands which open on the "spinnerets" situated at the posterior end of the animal. These glands secrete a sticky fluid, which assumes a thread-like shape as it passes through the ducts. Exposure to the atmosphere instantly converts this viscid fluid into a silk-like thread, so that the spider seems to really "spin" her web.

Having selected a suitable site for her snare, the spider secretes a short thread and fastens the free end to what will be the upper limit of the web. She then allows herself to drop, secreting a silken thread as she goes, until she reaches what will be the lower boundary of her net. Here she fixes the other end of the strand. Thus the foundation of her web is laid. The industrious creature allows herself no rest until she has completed her snare, secreting strand upon strand, and interweaving them most skilfully. She has now laid a perfect trap for the unwary fly. A spider's web is made up of two kinds of threads; a few thicker ones, which form the highways for the spider, and a great number of very fine strands which act as the snare. Having completed operations the spider retires to a dark corner and awaits events. If fortune favours her it will not be long before a fly or other insect finds his way into the "parlour." The amount of violence with which the web is shaken by the struggles of the victim at once informs the spider whether it is a large creature, such as a wasp, or a small one, such as a fly. Her mode of procedure varies accordingly. If a fly be caught the 
spider pounces down upon it with lightning rapidity, grasps it with her two front legs, and, holding on to the web by means of her two middle pairs, uses the hindermost pair, and the spinnerets to wind a net of silk round her victim. If she be not hungry she leaves her captive thus bound, figuratively speaking, hand and foot, until she needs a meal. If she be hungry she at once paralyses her prey with the poison she secretes, and then proceeds to suck out its life-blood. When she has absorbed all the nutrient matter she casts away the dry husk.

If, however, her victim be a wasp the spider approaches it very warily, taking great care to avoid the sting. She commences operations with the head, winding it round and round with silk, and then works backwards. It not infrequently happens that the wasp is too much for the spider, and bids fair to wreck her net in the violence of its struggles; the clever spider then, on the principle of "discretion is the better part of valour," cuts the web all round the dangerous prisoner, which is thus allowed to drop away.

Each day I feed my spider. A black ant is daily sacrificed to her. Sometimes for an ant I substitute a little ball of paper. As soon as it touches the net the spider pounces down upon it only to find herself the victim of a trick which she seems to resent, for she retreats in disgust, returning later to cut away the useless encumbrance.

It was stated above that the spider is cruel and voracious. But she is worse than this-she is a cannibal. I look forward to the time of her courtship, when the male, who is smaller than the female, will timidly approach and dance before her in hopes of winning her approval. If he fails to please she will dash at him, and he will run for his life, for if she catch him she will devour him without compunction. I regret to have to relate that it often happens that even after the lady spider has accepted one of her suitors as her spouse she kills and eats him. Such are the dire 
tragedies that frequently occur in the seemingly peaceful bungalow !

The cricket is another of my unbidden guests. He is a cousin of the grasshoppers, and, like his relatives, a marvellous jumper, hence it is not easy to capture him; you think you have him in a corner, when, like De Wet, he escapes you. The cricket is not a favourite of mine, for his continued shrill stridulation is to me a most unpleasant sound. The males only do the chirruping; it is their love song. Bates, writing of the European field cricket, states: "The male has been observed to place himself in the evening at the entrance of his burrow, and stridulate until a female approaches, when the louder notes are succeeded by a more subdued tone, whilst the successful musician caresses with his antennæ the mate he has won." Although the chief object of stridulation is to attract the female, it is not the only one. White in his Natural History of Selborne declares that the house cricket, when surprised at night, uses its voice to warn its fellows. Dr. Scudder was able to excite a cricket to answer him by rubbing a file with a quill.

When a cricket is "calling" his legs never move, his wings, however, vibrate in a horizontal plane. So fast is the motion-24,000 vibrations a second-that the eye can scarcely follow it. If the wing-cover of a cricket be examined under the microscope there will be seen projecting from the under surface a ridge divided up into some 230 teeth. This toothed-ridge is rapidly scraped across a smooth hard projection on the lower wing, and thus the irritating sound of the cricket produced.

Most naturalists will admit that, with the exception of man, the polymorphic insects-ants, termites, bees, and wasps-are the most wonderful animals in creation. Of these four families no fewer than three are represented in the fauna of almost every bungalow. These creatures, long before man came into existence, discovered two great economic truths, that the advantages of the division of 
labour are great, and that in combination there is strength.

A colony of black ants will probably consist of over twenty thousand individuals. These are divided into three castes or classes-winged males, females which are winged in earlier life, and wingless sterile females or workers. The two first classes are rarely seen, for the males are allowed to die after they have performed their function, and the females stay always under-ground in the nest and lay eggs. The ants which one observes wandering about the bungalow belong to the neuter class. They do all the work. They search for food and feed the females, they look after the eggs and pupæ, defend the nest, and heep it in order. Many species of ants make slaves and domesticate other insects. Lubbock has counted no fewer than five hundred and eighty-four species of crustaceans and insects which have been thus domesticated by ants. From some of these the ants extract a juice just as men obtain milk from cows. The intelligence of ants has been vastly exaggerated. Thus Huber thought that ants had a regular language. This and other assertions regarding these wonderful little creatures have been proved to be contrary to fact. There is now a tendency to go to the opposite extreme, and deny to ants powers which they really possess. Thus, because some observers saw ants carrying in their mouths what they took to be food-grains, but which were in reality the cocoons or pupæcases containing the young, it has been asserted that no ants store up grain.

My own experience, however, enables me to vouch for the grain carrying habits of the black ant so common in the bungalow.

In one of the ante-rooms a considerable quantity of barley was one day upset on to the ground. By the next morning nearly all this grain had been removed by the black ants. These industrious little creatures had piled it up in the next room; they had in one night removed sufficient barley to make a heap nearly four inches high. 
For their size ants are endowed with remarkable strength. An ant will carry off, apparently without the least exertion, a grain of corn or other load three times its own weight.

The wasp cannot be called a general favourite, for most people only know it by its sting. The sting, however, is really an instrument for depositing eggs, and is only incidentally turned into a weapon of offence or defence. A wasp will never sting unless frightened. The queen wasp is the finest specimen of feminine industry and maternal devotion found in the animal world. At the beginning of the hot weather the royal lady awakes from her torpor and founds a new colony. "I want you," writes Grant Allen, "to understand the magnitude of the task this female Columbus sets herself-Columbus, Cornelia, and Cæsar in one-the task not only of building a Carthage, but also of peopling it. She has no hands to speak of, but her mouth, which acts at once as mouth, and hands, and tools, and factory, stands her in good stead in her carpentering and masoning." Her nest is a veritable work of art. It is composed of a vast number of rooms, in each of which she lays an egg. When these hatch she carefully feeds and tends the larvæ, the while laying more eggs and extending the nest. The first perfect wasps to emerge are the workers; they then relieve the over-worked queen of all duties except that of laying eggs. Of these a queen wasp will produce five or six thousand.

Disliked even more than the wasp is the white ant, which, by the way, is not an ant at all, belonging as it does to quite a different order of insects. Our dislike of white ants, or Termites as they are more properly called, is certainly well-founded, for in the bungalow they are an unmitigated nuisance. Out of doors, however, they perform a most useful function. They are for countries with hot dry climates what the earthworms are for damp temperate regions, nature's ploughmen.

As every Anglo-Indian knows, these "worst abused of all living vermin" feed upon dried wood. 
But the succulent body of the white ant is a morsel to the taste of every bird, and as the body of the termite is so conspicuous it has to approach under cover all objects not actually on the ground. The white ant, therefore, builds a tunnel as it progresses. These trenching tunnels frequently appear on the bungalow walls, and marvellously quickly do they grow. The termites work from the inside, and at the incomplete end of the passage they may be seen in numbers adding fresh pieces of mould. The earth for these tunnels is usually brought up from under-ground; thus much of the deeper soil is carried to the surface.

With the cisst advent of the rains we are invaded by a new form of the white ant-the winged form. They come in thousands, they are the young males and females ready to assume sexual relations, and to become the kings and queens. The swarming of the white ant constitutes a veritable harvest for spiders, lizards, bats, toads, \&c., and glad are we that these winged forms have so many enemies that prey upon them, for although the males and females themselves do not attack wood, each female is able to produce in her time not far short of a million eggs, most of which will develop into the wood-infesting forms.

Want of space prevents me from even enumerating the other inmates of the bungalow, the mice, rats, toads, flies, moths, fish-insects, ticks, mosquitoes, and other parasites. These creatures are all around us, each living its own little life, each fulfilling its purpose in the plan of the universe. There is, indeed, a considerable bungalow fauna, each member of which forms a study in itself, a study which any man, be he scientist or no, may take up, and even if rewarded by no great discovery, he will not look upon his labour as lost, for he will at least have passed profitably and with pleasure what would otherwise have proved many weary hours of imprisonment in the bungalow. 


\section{THE NATURALIST IN HIS VERANDAH.}

$\mathrm{I}^{\mathrm{T}}$ is May, and I am in the hills. The delights of May

in the Himalayas are second only to the pleasures of an English spring. I speak as one with authority, for as I lounge in the verandah my ear is delighted with the homely "caw" of the crow and the pleasant note of the cuckoo. In the distance are visible sun-capped snow peaks rendered quite ethereal by the bluish haze which surrounds them; near at hand the flowers are at their best. A few late roses remain ; the carnations are in full bloom, honeysuckle entwines the pillars of the verandah in wild profusion. The decided colours of the geraniums, phlox, portulaccas, and nasturtiums form a pleasing contrast to the delicate shades of the sweet-peas, and the scent of the mignonette adds to the charm of the whole. But I must not continue in this strain, or readers will begin to think that this is an advertisement for somebody or other's best seeds-one of those concealed advertisements which are now so frequently inflicted upon us, and of which it is difficult to see the use, for on the discovery of the hoax, the reader is so indignant that he vows that no power on earth will make him buy the article in question. If it be a patent medicine he would far rather die than purchase the offending drug.

This, however, is not an advertisement for seed, hence I shall confine myself to saying that at this season of the year a hill garden is a veritable paradise, and the verandah the throne from which the panorama may best be viewed. Nature is at her best. It is a case of where only man- 
and flies-are vile. The fly is bad enough in the plains, but in the hills he is a thousand times worse. When I walk through the bazaar all the shops appear to be draped in mourning, and it is only on approaching close to them that the mourning veil, composed of a phalanx of flies, arises, and reveals what the shopman has for sale. I cannot see the use of flies. I love animals from the amoeba upwards. I, however, except the fly. It is no use pointing out to me his beautiful structure, the marvellous formation of his mouth, and the wonderful build of his feet, which enable him to walk upside down. I can see nothing good in him. He does no work, he fritters away his whole time, buzzing about to no purpose, and then settling down on the spot most calculated to annoy a human being. I take a savage delight in torturing and killing him. The sight of a fly raises in me all my latent savage instincts and passions.

Having thus delivered myself of this tirade against the most unwelcome occupant of my verandah, I can speak with a calmer mind of its more interesting inhabitants. Attached to the under side of the roof is a swift's nest. This is a work of art. It is built chiefly of rubbish with a sprinkling of feathers. Both birds work at the nest, collecting pieces of straw, \&c., from far and near. These they glue to a rafter or to each other by means of their viscid saliva. This pair of birds have commenced their family cares early, for, as a rule, it is not until later in the season that swifts begin to think of breeding. Nevertheless, this nest has been completed for some time, and now contains two young birds which keep their parents busy finding food for them. The entrance is close up against a rafter, and it is marvellous how the birds manage to fly straight into the nest without damaging it or without knocking against the roof.

The only other avine inhabitant of my verandah (for I do not count the stray crows and other birds which sometimes venture in when I am not there) lives in a cage. $\mathrm{He}$ 
is a tame hill myna (eulabes intermedia). This species has no tail and in consequence is a ludicrous object; he is as greedy and impudent a bird as one could wish to meet. His appetite is appalling and he has acquired many bad habits. He does not swear like the sailor's parrot, but he makes up for this deficiency by imitating with unerring exactitude every disgusting noise he hears. Expectoration à la Indienne is his speciality. My myna is assuredly the most vulgar bird in existence, and that is saying a good deal!

There is, or rather was, another nest hanging from the roof of my verandah, for a queen-wasp in a foolish moment selected this unusual site for the foundation of her colony. The queen-wasp is the most industrious of animals. For getting through really hard work the ant-to use an Americanism-is not in the same street with her. As soon as the warm weather sets in she awakes from her hibernating slumber, and having hastily breakfasted, selects a site for her nest. She then flies to the nearest palings or any other structure made of wood, and proceeds to rasp off shavings with her powerful jaws. These she works up in her mouth into a kind of paper. It is a mistake to think that the Chinese first invented paper. Wasps were paper-manufacturers long before the heathen Chinee appeared on the earth. The queen-wasp constructs her nest out of the paper she has made. She fastens it to the roof by a stalk which expands into an umbrella, under which she constructs, with amazing rapidity, a number of hexagonal chambers. These open downwards. In each she lays an egg from which a grub soon emerges. The grubs spend the first days of their existence hanging downwards, with open mouths, from the roof of their chamber. Her hard worked majesty has then to feed her offspring, in addition to building new chambers. She has further to add to the walls of each cell, so that it may keep pace with the growth of its occupant.

Yesterday morning as I watched the eager mother fussily attending to her offspring, giving now one, now 
another, a drop of honey, I planned a crime. I said I loved animals, so I do. I am not inconsistent. Wasps are excellent things, but like other excellent things one can have too much of them. Again, like some good things, they are seen to best advantage at a distance. Accordingly, I waited until the mother, having exhausted her stock of honey, flew away to obtain more; then I hastily folded up a newspaper, jumped up on a chair, and with the paper knocked the nest on to the ground. To snatch up the fallen nest and carry it into the bungalow was the work of an instant. The fell deed was rapidly executed. I did not waste time, because I was most anxious to put the chik between myself and the irate mother, and I knew she might return at any moment. Once inside, I could examine at leisure my prize. It was the size of a large walnut, and very light. It contained seventeen chambers, arranged round a central pillar of papery substance. Seven of the cells contained larvæ; these were all in the earlier-formed cellsthose nearest the central columns. Some of the ante-chambers contained unhatched eggs, while others were still empty, an egg not having yet been deposited in them. The largest of the larvæ was about three-quarters of an inch long. The wasp larva is a yellow sausage-shaped creature, tapering off towards the extremities. Its soft body is ringed like that of a worm. At the front end, which is dark in colour, is the mouth. The grub hangs mouth downwards from the roof of its chamber. In this case one of the grubs was just about to undergo metamorphosis, and had the nest not been disturbed, would, in a few days, have emerged as a worker-wasp, and at once set to work to help its mother. Alas! this was not to be; cruel fate caused me to cut off seven most promising wasp grubs on the very threshold of their career.

On my verandah stand a row of flower-pots, which pots, I regret to state, contain inhabitants other than the plants for which they were designed. Thus every carnation plant is preyed upon by at least one caterpillar, and 
although the mali and I daily kill numbers of these destructive creatures their number never seems to diminish. They apparently arise from nowhere, and their continual advent is the best argument $I$ know in favour of spontaneous generation. The carnation-infesting caterpillar spends most of his time inside flower-buds. With his sharp and powerful jaws he bores a neat round hole in the bud, and literally eats his way in. Once inside, he makes short work of the bud.of which he leaves nothing but the calyx. He then proceeds to the next bud, and repeats the operation. Greediness is, I am sorry to have to admit, not an uncommon trait among animals. The caterpillar is greed personified. I should not care to state how many times its own weight of food it devours in a day. The growth of the caterpillar of the privet-hawk moth will enable us to form some idea of the quantity of victuals a caterpillar contrives to put away. It takes thirty-two days to reach the respectable length of four inches-its size when full-grown. When first hatched, this caterpillar weighs one-eightieth of a grain ; on the eighth day it will weigh one-eighth of a grain. By the seventeenth day its weight will have reached three and a half grains. In its twentieth day it will turn the scale against a twenty-grain weight, while before it terminates its caterpillar existence it will weigh one hundred and twenty-five grains. Thus, during the month of its life, its weight will have increased a thousandfold.

But to return to our carnation-hunting caterpillar. I have never taken the trouble to weigh a specimen on each day of its existence, but I believe that its growing powers are in no way inferior to those of the privet-hawk caterpillar. The pace at which it works is appalling. I caught one of these animals yesterday, and put him, to his intense disgust, on my desk. I next plucked a young carnation bud, placed it beside the caterpillar, and drove him on to it. At first hesulked and would take no notice of the bud; then hunger overcame his pride, and he attacked the food 
set before him. By the time he had been at work, exactly four minutes, he had eaten away a round hole in the calyx ; at the end of ten minutes he had eaten so much of the inside of the bud that fully one-fourth of his body had become lost to view! Caterpillars have many enemies. They are defenceless creatures, with soft succulent bodies, and a number of animals, such as birds, ants, spiders and wasps, are constantly on the lookout for these dainty dishes. Caterpillars, therefore, have to adopt all manner of devices to escape being seen. Thus many of them feed at night. This the carnation-infesting caterpillar does, but he goes one better : during the day he gets inside a bud and eats away in perfect security. This morning I picked a white carnation which had just expanded and put it in my button hole. In a short time, to my surprise, the petals began to drop one by one. Then I noticed a caterpillar inside the flower whose nibbling had caused the petals to drop off. So neatly had he stowed himself away in the base of the flower that when I plucked it I noticed nothing wrong. That caterpillar is now on a cigarette tin devouring voraciously what remains of the unfortunate carnation.

On my verandah some seedlings are growing : the leaves of one of them bear the marks of the ravages of an herbivorous animal. The offender is now starving to death in a tin box on my daftar table. He is a caterpillar, which any but an experienced eye would take to be a little mass of sand and twigs. In order to escape detection this wily creature secreted from all parts of his body a sticky fluid, and rolled in the sand so as to secure a coating of that material. He next rubbed up against every little dead stick he came across, until he now looks for all the world like a bundle of twigs. He acts up to his disguise. He will remain motionless for any length of time, and when he does move, his gait is so slow as not to be visible to the human eye. Thus, this impostor is able to feed in broad daylight secure from the hungry birds and wasps who all around are on the lookout for caterpillars. I caught him 
red-handed feeding in broad daylight. For his crime he is to suffer the extreme penalty of the law.

Although butterflies and moths cannot, strictly speaking, be termed inhabitants of my verandah, their visits are so frequent that during the hours of sunshine one or two are always present. Hence I conclude with a word about them. The butterflies and moths, though numerous, are not at their best. The larger species, such as the immense Atlas and the Half-moon, do not appear until the rains. The difference in character between the butterfly and the bee forms a most interesting study. The former is a lighthearted trifler; he leads an utterly selfish life; he has no family cares, no aims in life except enjoyment, hence he fritters away his time. Watch a butterfly for five minutes. It is not often that you will be able to keep him in sight for so long a time. He first settles upon a leaf, then flies off, performs a number of zig-zag evolutions in the air, and then returns and sits on, perhaps, the very next leaf. Now, a bee would, in the first place, never waste her time in visiting leaves which afford no food, and, secondly, if she did, she would pass direct from one leaf to another without performing a number of elegant but useless gyrations in the air. The butterfly lives for himself, the bee for others. The butterfly exists that he may enjoy life; the bee that she may work for and support a large family. Not a moment does the busy bee lose in frittering away her time. She goes to one of the honeysuckle plants that creep up the pillars of my verandah, and visits flower after flower in the most methodical fashion, taking from each a sweet draught of honey, and in return acting as pollen-carrier. I have timed her, and it is no unusual thing for a bee to visit seventeen flowers in a minute. So hard does she work that some naturalist-I forget whoonce declared that bees had to take so much stimulant in order to brace themselves up for their labours that they do most of their honey-seeking in a state of semi-intoxication. Whether this is the case I do not know. But two things 
I do know-first, that this assertion caused a great scandal among teetotallers, and, secondly, that the butterfly does not get through sufficient work to justify his taking stimulants. 


\section{THE CUCKOO.}

THE cuckoo is now making himself heard in most of the Himalayan hill stations. I must confess that this bird is a particular favourite of mine, for not only is his note most homely and cheerful, but he is in every way a most interesting animal. The cuckoo is the biggest villain in the feathered world; and we must all admit that there is something fascinating about wickedness, especially when it assumes a picturesque form. The villainy of the cuckoo is more than picturesque, it is thorough-going and consistent. This bold bad bird has no relapses into a moral life; he knows no periods of repentance. He begins his days with a $\sin$ and passes through life steeped in iniquity. He commences operations by a foul murder, and follows this up by a life of unparalleled duplicity and deceit, yet he is always cheerful. A bird that can laughingly call out "cuckoo, cuckoo" at 2 a. $\mathrm{m}$. in the pouring rain cannot be cursed with a conscience. The cuckoo is a living example of the truth that the wicked flourish like a green bay tree.

The cheery note, which we all delight to hear, is the voice of the male, whereby he informs his mate of his whereabouts. The cuckoos' mode of life renders such a call note most necessary, for they are outlaws. Their hand is upraised against all other birds, and in return the other birds, especially the smaller ones, literally mob them. Hence it often happens that the cock-bird becomes separated from his spouse and desires to inform her of his whereabouts. The cuckoo after his own fashion leads an orderly 
life. He is guided by maxims. Of these the chiefest declares that it is folly to do yourself that which you can make others do equally well for you. "Why should we," say the wily cuckoos, "hatch our own eggs and feed and rear up our young when we can get other stupid birds to do both for us?"

In order to live up to this maxim the cuckoo has to lay its eggs in the nest of another bird. This is no child's play, considering that at the laying season all birds are busy near their nests. The cuckoo has, however, several ways of surmounting this difficulty. One method is exceedingly simple. It is to go up to some smaller bird, such as the pipit, and drive it off its nest, then to drop into the nest its own eggs while the unfortunate victim looks helplessly on screaming. This, however, is a rough and unskilled procedure, quite unworthy of an accomplished villain such as the cuckoo, hence it is not very commonly practised.

A more favourite method is for the cuckoo to mimic the appearance of the bird in whose nest it intends to lay its egg. Thus the black cuckoo of this country very closely resembles the drongo. The counterfeit is so good that the drongo itself cannot distinguish the black cuckoo from one of his own species, and, although most jealous of any intruder near its nest, allows the cuckoo-the lion in the ass's skin-to hover about quite near the nest. And the moment the hen drongo quits the nest in flies the cuckoo and deposits her egg with her bill.

The arch-hypocrite, however, is the cuckoo who takes upon him the form of the sparrow-hawk, thereby playing the rôle of the ass in the lion's skin. The male cuckoo, thus disguised, hovers about the nest upon which his mate has designs. The owners of the nest take this wily scoundrel for a hawk with its eye on their home. The brave little defenders, therefore, leave it and try to drive him away; while they are thus occupied, the female cuckoo deposits her egg in the nest. When the dupes have ceased 
chasing him the male cuckoo settles down upon some branch and calls to his wife to join him, and together they chuckle over the success of their ruse, and fly off to repeat the trick on another bird.

Some cuckoos carry their villainy yet a step further. After the hen has deposited her egg in the strange nest, she, in order to secure that the fraud shall not be discovered, takes up in her beak one of the eggs already in the nest and drops it on to the ground so that it is smashed to pieces !

The deception is rendered all the more perfect by the fact that the egg of the cuckoo usually closely resembles those of the owners of the nest. There are several races of cuckoos, each of which always deposits its eggs in the nest of one particular species, it may be that of the sparrow, it may be that of the robin, the myna, the thrush, the pipit, or a score of other birds; but it is always the nest of the same kind of bird. The resemblance of the egg of the cuckoo to that of its foster-parent is supposed to be due to the influence of food during the nestling period of each particular cuckoo.

The female cuckoo will commit murder in order to insure her egg being properly hatched. If she finds a young bird in the nest in which she intends to place her egg, she savagely drags out the helpless creature and kills it. The reason for this is obvious. Having a young one the fostermother might not care to hatch another egg; and even if she did hatch it her true offspring would have such a long start on the young cuckoo, that the latter might find it difficult to obtain sufficient food.

The young cuckoo is born blind; but blindness does not deter him from committing deeds of evil. Since the egg from which he is hatched is generally laid after those from which his foster-brethren emerge, these latter are born first. The newly-hatched cuckoo gropes about the nest until he finds one of his foster-brothers. He then struggles and wriggles about until he succeeds in hoisting the hapless youngster on to his back. The young murderer then 
slowly but surely makes for the opening of the nest with his living load, and quietly heaves it overboard !

Having accomplished this the little blind monster feels about for his next victim; nor does he rest satisfied until he has ejected from the nest all his foster-brethren. He is now happy, for he will receive all the food brought to the nest by the parent birds, and a greedy creature he is, devouring anything and everything. His appetite is simply appalling. In about a fortnight the young cuckoo is completely fledged and is able to leave the nest; but even then this dissipated bird makes his foster-parents toil for him. They live in terror of him, and well they may, for he is a cruel tyrant. He makes them feed him with worms until he has grown so big that they have to perch on his shoulders in order to reach his mouth. He is far too lazy to take these morsels from their beaks, they have literally to drop them into his mouth. Yet worse, the cuckoo has not a spark of gratitude in his nature.

Bishop Stanley relates how a young cuckoo, adopted by a thrush, pecked out one of his foster-mother's eyes because she could not resist the temptation of swallowing a fine plump worm which the cuckoo had expected to receive. Such is the character of the gay cuckoo. 


\section{VII.}

\section{AN EIGHT-LEGGED ISHMAELITE.}

THE spider is a sadly neglected animal. While dozens of eminent men have written in praise of ants, bees, and wasps, scarcely one has deigned to notice the spider. The arachnids have been passed over unremarked by those who have lauded the virtues and exaggerated the intelligence of the hymenoptera. Yet the spider is an animal far more interesting than any social insect. In intelligence and valour the spider is immeasurably superior to ant, bee or wasp. Then, again, with a few exceptions spiders are harmless to man, and they wage unceasing war against mosquitos, flies, black-beetles, and other insect pests. Bees certainly give us honey, but as a set-off they have nasty stings, while ants and wasps are unmitigated nuisances.

Let us, therefore, give the spider his innings. When studying the character of an animal we should contemplate him in two aspects-in his relations to other members of his own species, and in his dealings with the rest of the animal world. In other words, we have to consider both his home and foreign policy. Thus studied, the spider stands forth as the Ishmaelite of the insect world. His hand is against all insects and their hand is against him. This latter fact is often.lost sight of ; for most people are of opinion that spiders have matters all their own way. They look on a spider as a savage and immoral beast of prey; they regard him as a terror to all good and wellbehaved insects, as a monster who is afraid of nothing. This is not so. Spiders are hunted quite as much as they 
hunt. A spider has a dual character; at one time he is a fierce beast of prey; at another the timid fugitive trying to escape from the jaws of his hungry oppressor. For a skilled Nimrod commend me to the spider. It is true that he has as yet invented neither gun nor rifle; but to employ such a weapon is a confession of weakness. If you can catch your game by running after him, of what use is a rifle?

The majority of spiders secure their prey by means of traps. The web is the snare most commonly employed. Since everyone knows how a spider builds its web, I shall confine myself to a few remarks on the completed structure. There are webs and webs. Many are the degrees of proficiency in the art of web weaving. The geometrical spider is the most skilled architect. He constructs a circular web with a number of lines radiating from the centre. Strength and lightness are here cunningly combined. Not long ago I espied a spider half hidden among the leaves of a virginian creeper. I took a twig and with it prodded the unfortunate arachnid. He, not without reason, resented the treatment, and kicked out at the twig, and while doing so attached a line of silk to it. Observing this I proceeded to walk away with the twig. This action put the spider in a quandary. By nature he is a most careful animal. He wastes nothing. Break up his web and he will eat what remains. Now here was this spider. He had attached a silken line to a twig, which, contrary to his past experience, began to move away from him. He had either to let out more line or lose what he had already given out. $\mathrm{He}$ found himself, in fact, in the position of many an unfortunate human investor. The spider, doubtless with many misgivings, adopted the former course. When he had given out some twenty feet of line I stuck the twig into a tree, so that the silken thread formed a bridge connecting a tree with an angry spider. The line was able to support its own weight, which, considering its tenuity, was no mean feat. In order to see how much extra weight the 
line would bear, I plucked some blades of grass, and bending them at an angle hung them in a row on the line just as a washerwoman hangs linen out to dry. Five blades were successfully hung; the sixth, however, proved to be the straw that broke the camel's back-the line snapped. To me the experiment was interesting; the spider, however, did not appear to fully appreciate it.

Next in order of merit as web-weavers come the Retitel arice spiders, who build regular webs among the leaves of trees or in the angles of buildings. These webs are fixed above and below by lines of silk which run in all directions; other spiders, again, make their snare in the shape of a silken tube which they construct in any hole or fissure they can find. The mouth of the web is open, with one or two viscid lines placed across it. In these the unwary insect becomes entangled. The spider dashes out with lightning speed and drags its prey into its lair. Other spiders, again, make their own holes in the ground and line them with silk. Over these dens they construct a silken trap-door, which closes on the unfortunate insect whom curiosity prompts to "prospect" the hole. The gossamer spider can scarcely be said to build a web at all. His traps consist of a few ethereal strands of finest silk upon which he floats through the air in a truly mysterious manner. Many spiders do not construct snares. They sit hidden until their prey approaches, when they dash out and seize it. The ambush selected varies with the species. Some are content to sit concealed in a hole. The majority, however, occupy the centres of flowers or twigs, the colour of which is very similar to that of their body. A foolish butterfly comes along suspecting nothing, and in an instant it is in the cruel embrace of the spider, who loses no time in sucking out its life-blood.

One spider mimics a bird dropping, and he lies perfectly motionless exposed upon a stone. The fly, mistaking him for a tempting morsel, alights upon him, and shares the same fate as the luckless butterfly. Other spiders despise 
these refinements; they give open chase to their prey and rely upon their speed to secure it. Thus the big Indian house spider builds no web, nor does he lie in ambush. He wanders about until he espies a cockroach, when he gives chase, and if there be a few feet of open country before the black beetle can find cover, you may bet any odds on the spider. The little Sallicus, common all the world over, is another of the fleet spiders. He, however, carries a silken line about with him which assists him in accomplishing his wonderful jumps. Other spiders stalk their prey as skilfully as any cat. In short, almost every species of spider has its own peculiar method of securing its victim.

The spider is in its turn preyed upon. Wasps are the hereditary enemies of the arachnid tribe. Most cruel and implacable of the wasps is the mason-wasp, who is as barbarous towards the spider as the spider is to his victim. Indeed, if the spider gives no quarter, he gets none. When the mason-wasp espies a spider, she seizes him and maims him, and then carries him off to her nest, where he is eaten alive by the grubs. There is a small species of wasp which preys especially on those spiders which lie in wait for their victims in holes in the ground. When the wasp catches sight of what appears to be the lair of such a spider she at once enters it. Being not unlike a blue-bottle fly in appearance, the intruder is mistaken by the spider for this insect. The spider, thus deceived, makes a dash at the wasp. The latter pretends to be greatly alarmed, and runs back out of the hole with the spider close behind. Once outside, the wasp turns on the spider, and before the latter has appreciated what has happened, it is in the cruel embrace of the wasp, receiving an injection of paralysing poison. The wasp then adds insult to injury by dragging the disabled spider back to its own hole, in which she lays an egg. This being done, she covers up both insect and egg with earth, and then flies away, feeling that she has left a plentiful supply of food for the larva to eat when hatched. The ichneumon 
fly treats spiders in a very cowardly way. It lays an egg on the abdomen of the latter; when the larva emerges from the egg it eats its way into the body of the spider and literally sucks out the life-blood of its victim.

The spider instinctively recognises the wasp as its enemy and has devised a number of methods of escaping from the attacks of its foe. A favourite device is for the spider to assume the form of a leaf. Some forms simulate green leaves, while others affect the appearance of withered leaves. In either case, when the wasp approaches dangerously near, the spider drops to the ground in the slow manner of a falling leaf. The spider cleverly regulates the speed with which it falls by spinning an invisible line.

We have now to consider the spider in her relations to her own species. And in common honesty, we must admit that it is in private life that the spider appears to worst advantage. If she is cruel to other animals, the spider is brutal to her own kind. I use the pronoun "she" advised$1 y$, for I regret to have to state that in the spider world the female is far more fierce and depraved than the male. Have you ever seen a lady-spider being wooed? If not, make a point of doing so. Among spiders courting is a most dangerous occupation. In the case of human beings the male has only to fear a refusal, or at the very worst he may be somewhat violently put out of the house by the irate parent of his inamorata. A spider who goes a-courting carries his life in his hand, for the lady is always the larger of the two, and a fiercer creature does not exist, since she invariably tries to devour her rejected suitor. Far worse than this, she has been known to eat up her spouse when she has grown tired of him. She is a cannibal of the most aggravated kind. Watch her as she takes up a position in the centre of her web. In the far distance, a humble admirer is seen approaching. At first his gait is rapid, but as he nears the lady he becomes extremely wary, being ready to turn and beat a hasty retreat should she "go for" him. When the intrepid suitor has arrived within about four inches of 
the female he proceeds to show off his dancing. At first the dance is slow; it is, in fact, a series of balancing feats. Having stretched out all his eight legs, the male spider folds in those of one side as far as he can without overbalancing himself. The female watches him eagerly, constantly changing her position so as to obtain a better view. If she appears satisfied, the male moves in semi-circles towards her. She will in all probability resent this and make a dash at him. He of course runs away, but, as she does not follow him, determines to try his luck again, and a second time edges up to her by means of a series of semi-circular motions. The female now joins in and the fun becomes fast and furious. They both whirl round in terrific excitement. Yet again the male retreats and resumes his semi-circular movements. The female has by this time worked herself into a positive frenzy. She stands up on her hind legs and in this attitude determines whether she will accept her suitor or not. If she does, they embrace ; if not, the male will show a fine turn of speed, for he literally has to run for his life.

Seeing that the relations of the sexes are thus strained, it will not be a matter for surprise that spiders of different species are not very a micably disposed towards one another. Each spider appears to regard every other as his natural enemy. A spider sees nothing wrong in killing his neighbour and seizing his web. A fight between two of these animals for a web is an amusing spectacle. They do not as a rule use their falces when fighting. The contest partakes more of the nature of a wrestling match. There is a great deal of manœuvring for the grip. He, who secures this, wins the day. The antagonists keep revolving, jumping over and passing under one another, until one makes a mistake and is seized in a disadvantageous position by his adversary, who loses no time in weaving a net for him. The vanquished spider, bound hand and foot, starves to death, while the web becomes or remains the undisputed possession of the victor according as he is the attacker or defender. 
The weaker spiders practise many wiles in their contest with their larger and more powerful brethren. It is quite common for the smaller one, when being chased, to cut with one of its posterior legs the line behind it. This probably causes the pursuer to fall to the ground, and thus gives the fugitive a chance of escaping. There is a feeble longlegged spider which builds webs in the corners of rooms. What this creature lacks in strength, it supplies by craft. When attacked it gathers in its feet together at the centre of the web and swings itself round with great velocity, so that it appears like a mist on the web, and offers no point at which its adversary can strike. So weak is this long-shanked spider that it takes a considerable time to despatch the fly which it has caught in its net. The fly does not suffer its protracted execution in silence ; it makes a terrible noise. Buzzing of any description always excites spiders. Every spider in the neighbourhood hears the cries of the tortured fly, and, associating them with breakfast, makes for the spot from whence the sound proceeds. The captor of the fly has no chance in open fight with his adversaries, so having rapidly spun a web round his struggling captive, he cuts it away from the web and allows it to hang by a line. When the other spiders arrive at the spot they find nothing and retire in disgust. Then the wily long-legged arachnid is able to enjoy his meal in peace and quietness. Spiders, in spite of the large number of eyes they possess, appear to have but poor sight. A spider who will not notice a fly held half an inch from his web will be excited by the least buzzing noise. "By gently touching metal strings stretched on a piece of wood," writes Hudson, "I have succeeded in attracting spiders on to the strings, within two or three inches of my fingers; and I always noticed that the spiders seemed to be eagerly searching for something which they evidently expected to find there, moving about in an excited manner and looking very hungry and fierce."

What I have said may perhaps lead people to form a very low opinion of the character of the spider. Arachnids, how- 
ever, are not utterly depraved; they have their redeeming features. They are most intelligent and brave, and the females are excellent mothers to their young. The rash fury with which the female wolf-spider defends her children cannot fail to excite admiration. Sufficient has been said to demonstrate that the spider's intelligence is of a very high order. Instances might be multiplied indefinitely. I may cite the clever manner in which a spider cuts away a piece of paper or other useless object which has become entangled in its net; and the still cleverer way in which it tackles a wasp caught in the web. It never for a moment comes within reach of the sting. Finally, the spider has discovered the use of the plummet. It often happens that when a spider constructs its web between two trees there are no branches or other objects to which the lower threads can be fixed. The spider overcomes this difficulty by descending to the ground and attaching a line to a small stone or lump of clay. It next hoists up the stone or other object to what it considers a safe position, well out of the way of any small animal that may chance to pass along the ground under the web. That such a stone acts as a plummet for keeping the web taut may be proved by raising the stone, when the web will immediately begin to collapse, but will become extended again as soon as the stone is lowered.

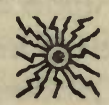




\section{VIII.}

\section{INSECT INVADERS.}

$W^{E}$ in the Himalayas are suffering from a foreign invasion. Black-mail is being levied on all sides by a locust army which is sweeping across the country. The locusts are evidently on one of their migratory expeditions. They are travelling in millions from north-east to southwest. A swarm of locusts, when you are close up to it, looks for all the world like a storm of dirty snow. Each locust has the appearance of a brownish snowflake, each moves in a slanting direction with the indescribable fluttering motion so characteristic of falling snow. The snowstorm appearance is only produced by those locusts which are a little distance away. At very close quarters the rapid motion of the wings is obvious. Migrating locusts usually fly some little height above the ground. In the Himalayan tract, however, there is practically no level ground, so that at one moment the flight is far above the surface of the earth and at the next almost in contact with it.

I happened to be going along a ridge just as the swarm was passing over, and rode through it. The experience was not a pleasant one. The locusts, being unable to control their movements, fall upon one like rain, or rather hail. My horse became very restive, and seemed to object strongly to the novel experience. Although the insects were not settling, many were resting on the ground. When disturbed by the approach of the horse, the resting locusts jumped into the air just as a grasshopper does, but while still rising, the wings unfold and thus convert the jump into flight. 
Many observers assert that a swarm of locusts make a great noise. It is thus described by the poet Southey:

"Onward they came, a dark continuous cloud

Of congregated myriads numberless,

The rushing of whose wings was as the sound

Of a broad river headlong in its course ;

Plunged from a mountain summit, or the roar

Of a wild ocean in the autumn storm,

Shattering its billows on a shore of rocks."

The prophet Joel describes the noise as like that of chariots, or a strong people set in battle array. I must confess. that I heard no noise at all. It is true that the swarm through which I rode was neither very thick nor very extensive, and my horse was trotting. But even taking this into consideration, it is obvious that the above descriptions must be taken cum grano salis, and that allowance must be made for poetic and oriental imagination. The ancients were prone to exaggerate, as the Arabic account of the locust will show: Three feet long, with a head like that of a horse, having the eyes of the elephant, the neck of the bull, the horns of the stag, the chest of the lion, the belly of the scorpion, the wings of the eagle, the tail of the serpent, the thighs of the camel, and the legs of the ostrich, but so powerfully spined as to be used as saws by the women !

The locusts which compose the present flight probably belong to the species Acrydium peregrinum. They are smaller than those I have seen in the plains and vary in colour from a brownish-yellow to bright red, like that of a boiled lobster. On the wings, of which, of course, there are two pairs, are a number of brown markings. The swarm of locusts which has just passed over is rather a straggling one. At first the locusts were few and far between, the next day they came in greater numbers, but it was not until the third day that the main swarm passed. This was an almost solid phalanx of, I should say, roughly one mile in length and half as broad. At their approach the members of the advance guard, which were feeding in the neighbourhood, 
joined the main body and passed on. On the fifth day there was scarcely a locust to be seen.

It has often been asked how far a swarm of locusts will travel. Certainly 1,000 miles is no uncommon distance, but, of course, the flight will usually rest at intervals on the journey. However, locusts are able to fly for considerable distances without resting. Last time I came out from England the ship passed through a swarm of locusts in the middle of the Red Sea.

Why locusts migrate is an unanswered problem. It is true that they are usually born in dry sandy places where there is little food to be obtained. We can, therefore, understand them leaving such a place. But why do they migrate so far? Why do they pass over very fertile tracts? Why, for instance, did not the swarm of which I have spoken settle down in the green fields and gardens in this district? Then, again, locusts often migrate from fertile to sandy places. The reason of this may, however, be that dry soil is essential to the hatching of their eggs. Locusts will eat anything and everything, from green foliage to old boots, muslin curtains, and, if there is nothing else to be obtained, one another. Although all is grist that comes to their mill, locusts, like human beings, have preferences. They only eat muslin curtains faute de mieux. In this neighbourhood they have shown a predilection for madua. They have also done full justice to the tomatoes. The damage they have wrought is very local. Not a single locust, except one I captured and brought in with me and then martyred on the altar of science, has entered my compound, yet they overran the parade ground 400 yards away. In other places near by they settled in such numbers as to be ankle deep. It is an ill wind that blows nobody any good. The locusts have been a tremendous windfall for the crows and kites; these have had great sport in chasing and catching locusts on the wing. The Gurkha soldiers and the Mahomedans also eat locusts. The former pull off head, limbs and wings and curry what remains; the latter cook locusts in oil. 
Locusts should make excellent eating, for, under ordinary circumstances, they are clean feeders. However, I must admit that I have never had the courage to try.

The life-history of the locust is interesting. As may be surmised the female is prolific. Mirabile dictu, the Arabians were not far wrong when they made a locust say to Mohammed, "We produce ninety-nine eggs. If the hundred were completed, we should consume the whole earth and all that is in it." A locust lays from fifty to a hundred eggs. The female is larger than the male, and possesses at the hind end of her body four hook-like valves, by the repeated opening and closing of which she bores a hole in the ground. This forms a receptacle for her eggs. Firm sandy soil is a sine qua non for the locust's nest. The female first deposits some frothy mucous matter in the hole. In this she lays an egg. Then more frothy substance is deposited, then another egg, until the nest is full. The chief use of the mucous matter is to protect the eggs from the damp, which is very fatal to them. It will be noticed that the eggs which are first laid are at the bottom of the nest; these hatch out first, and to allow their young to escape a kind of irregular channel is left in the frothy substance.

The newly-hatched locusts are small and wingless editions of the adult. They congregate together, and, having devoured all the food to be found in the neighbourhood of the nest, proceed to migrate. Now is the time to stop them, for they cannot fly, having not yet acquired wings. They are, however, able to crawl over all natural obstacles. Nothing, but a smooth vertical surface forms an effectual barrier to them. The British Government in Cyprus have taken advantage of this fact, and have erected numbers of canvas screens, along the top of each of which is a strip of American cloth. The locusts swarm up the screens as far as the American cloth. This they cannot negociate, and in their endeavours fall into the jaws of death in the shape of zinc pits dug for their reception, and up the smooth walls of which they cannot climb. Before becoming fully grown, 
locusts moult or change their skins several times. At the fourth moult the wings appear.

Even a small plague of locusts, such as that which has lately swept over the Himalayas, does a considerable amount of damage, but this is as nothing compared with the awful ravages of a really big swarm. History records many instances. It is related that in the year 59I an infinite army of locusts, of a size unusually large, grievously ravaged part of Italy ; and being at last cast into the sea, from their stench arose a pestilence, which carried off hundreds of thousands of men and beasts. In the Venetian territory in 1478 , more than 30,000 persons are said to have perished in a famine occasioned by these terrific scourges. Major Moor gave some account of an army of locusts which ravaged the Mahratta country many years ago. The column they composed is said to have extended some five hundred miles, and so compact was it, when on the wing, that, like an eclipse, it completely hid the sun, so that no shadow was cast by any object, and some lofty tombs, not more than two hundred yards distant from the Major's residence, were rendered quite invisible. These belonged to a red species of locust, and they imparted to the trees, of which they had stripped the foliage, a sanguine hue.

Of late years there have been no very terrible plagues of locusts. This, however, must be attributed more to good fortune than to scientific progress. For, as regards methods of destroying these insect pests, we have made but little advance since the day when the Bashaw of Tripoli raised a force of 4,000 men to fight the locusts, ordering all to be hanged who, thinking it beneath them to waste their valour on such pigmy foes, refused to join the party. 
MEDIÆVAL NOTIONS OF INDIAN NATURAL HISTORY.

$\mathrm{A}^{\mathrm{N}}$ old translation of the Abbé de Guyon's book on the East Indies has recently fallen into my hands. One chapter of this work is devoted to the animals of the Indies. This chapter, in addition to being most entertaining reading, is instructive as showing how far natural history lagged behind other knowledge in the 18 th century. The translation was published in 1757 , and, with the exception of those portions dealing with natural history, is fairly accurate. The zoological part of the work, indeed, consists chiefly of quotations from Pliny and other veracious classical authors. As might be expected, the Abbé devotes much space to the elephant, and the tall stories which he relates regarding that sagacious quadruped are worthy of any Yankee. One of the best, which even the Abbé finds it difficult to believe, describes how an elephant perceiving his master was covered with wounds, lowered himself in the battlefield in order to let his master down without hurting him, and then proceeded to pull out with his trunk the arrows " with which he was all stuck over;" but, seeing that his master was losing all his blood, the elephant carried him back to the camp. The only parallel to the next story is that of the horse advertised for sale, and which, among other accomplishments, was able to play the piano; but this horse was a fool to the elephant which Mutianus, "thrice Consul of Rome, "saw. This animal knew the Greek characters, and wrote down the words spoken to him by picking out and arranging the letters. This elephant was by no means an exceptional one, for the Roman Consul tells of another who, having been severely punished by his master because he could not retain his lessons, passed the whole night in a 
contemplative attitude, and did that perfectly well in the morning which he had failed to do the day before. Almost every elephant, according to Mutianus, understands as much of the Indian language as relates to themselves.

If we may believe the learned Abbé, elephants have very decided notions of what is right and what is wrong. They have, for instance, a particular horror of adultery. In proof of this some stories from Elian are quoted. One faithful monster having caught his master's wife in adultery, went and stuck her and her accomplice through with his tusks, to show the husband his zeal and his fidelity. Another elephant went one better. Having killed the adulterers, he threw a covering over them in order to conceal, if possible, the sin from the public! Indeed, if we may trust the Abbé, the versatile elephant had once a very nasty habit of interfering in his master's domestic affairs. There was once an Indian from whose wife "years had taken the power of pleasing." The husband got disgusted and made away with her by cutting her throat and secretly burying her in the elephant's stable. Having performed this pleasant task, he took unto him another wife. The elephant fearing that she too might not wear well and have her throat cut, "took her up in his trunk and carried her to the grave of her predecessor. He opened it himself, and showed his new mistress the carcase of the former one. He made her look upon it with attention, and showed her by that act of cruelty and barbarity what was the character of him whom she had chosen as her husband." Unfortunately the Abbé does not tell us how the elephant managed to open up the grave, but he expressly tells us that the lady chose her husband.

After that of the elephant, the account of the rhinoceros falls rather flat. This creature does nothing clever except sharpen its horn against a stone. It, however, has wings like those of a bat. The horn of the rhinoceros, the Abbé informs us, is much employed by the Indian kings because "it sweats at the approach of any poison whatever." Even 
more useful are the horns of the unicorn and the wild ass, for liquor kept any time in these becomes a certain antidote against poison. The Abbé's account of the way in which camels are taught to kneel down will bear repeating: "As soon as they (the camels) are brought forth, they (their masters) bent their (the camels') four feet under their belly, and put a covering on their back, whose corners are loaded with stones, that they may not rise up during twenty days." Another interesting feature about the camel is that he "suffers himself to be devoured by the lion and the tiger without the least resistance."

Otesias's account of the manticore raises doubts even in the mind of the credulous Abbé. This monster has the face and ears of a man, blue eyes, and the rest of the body red, and nearly of the bigness, shape and strength of a lion. It has three rows of teeth with which it devours both men and beasts. "His tail, a cubit in circumference, was stuck all over with darts a foot in length and hard as iron, which he shot forth behind andzbefore to a hundred paces distance, and against whose poison there was no remedy." Presumably not even water from the horn of the wild ass! We should have liked to have further particulars about this monster of whom geology gives us no record. Whether he made good shooting with his arrow darts, and whether they grew again when once he had fired them, or whether he went and picked them up and replaced them.

It is instructive to learn that the dragon is only a serpent of extraordinary size, in whose head a precious stone is found, "which throws as much light as the diamond." This stone, however, loses its brilliance unless taken out the moment the dragon's head is cut off. This gem has another peculiar property. Ficinus says that if it be left for a time in vinegar, "it moves of itself, first in a direct line, and then describes several circles."

The Abbé next goes on to describe a species of ant as big as a fox, which has the property of finding out where gold is buried and digs it up. The smaller ants 
are fond of eating birds, so that those who keep these as pets " are obliged to set them on a stick fixed in a vessel full of water."

The Abbé gives some useful hints as to how to catch monkeys. "It is by this passion for imitation or mimicking everything that the apes teach men the manner of catching themselves. Some carry cups full of water or honey, rub their faces with it before them, and in their stead dexterously substitute glue, and then retire. The apes who see them from the top of a tree or rock come down to the cups to do the same, but they blind themselves, and thus put it out of their power to escape. Others bring boots which they put on and take off several times, and leave behind them smaller ones rubbed over with glue. When they are gone, the apes come and put them on, but cannot take them off or get out of the hunter's way. Sometimes they bring mirrors in which they view themselves in different attitudes, and leave others with traps which open and shut when they are touched. The ape lays hold of the glasses to look at himself, and immediately he finds his two fore-feet entangled, and himself unable to walk a step."

Although the Abbés account of the marine monsters of India does not contain so many tall stories as that of the land animals, the story of the flying fish does not leave much to be desired: "in summer it flies upon the mountains; and after autumn it takes itself to the sea, and becomes very delicate." According to the Abbé ostriches abound in India. These wily birds when chased pick up stones and throw them at their pursuers. The story of how ostriches hatch their eggs by looking at them exceeds the limits of the prelate's credulity.

He also disbelieves in the existence of the phœnix, but makes up for this unbelief by stating that there exists in India a bird which lives in the midst of flames without the least hurt, and obliges its young also to go into them. Clothes are made from the feathers of this singular species. All one has to do in order to wash such clothes is to put 
them in the fire for a short time. Fortunately for the dhobies, this bird is now extinct! After reading such an account as this, one cannot but admire the inventive power of some of the ancients, and despise the absurd credulity of the others. One further feels that now-a-days the study of natural history is a very tame affair compared to what it was in the good old days of yore. 


\section{$\mathrm{x}$.}

\section{A MISNAMED BIRD.}

THE myna has every cause to congratulate itself that it is not doomed to live in London. Were it an inhabitant of that great city, it would, undoubtedly, excite the wrath of the street urchin, just as the Bluecoat boys do ; like these latter, it would be generally mobbed, and greeted at every turn with the derisive question, "Who dipped your legs in the mustard pot?" It is a pity that half a dozen streetarabs could not be imported into India from London to sit as a committee for revising the names of Indian birds and beasts. It would only be necessary to Latinise the suggestions of the committee in order to provide our fauna with suitable names in place of the inappropriate ones which scientists have been pleased to give them. Could, for instance, any name be less suitable to the perky myna than Acridotheres tristis? Who has ever seen a myna looking dejected, or anything but plump and complacent? Jerdon objects to the name splendens for the common Indian crow, as tending to bring scientific nomenclature into popular dispute; the adjective tristis applied to the myna is a far grosser misnomer. The myna is almost as ubiquitous as the crow. In common with the latter bird, it affects the society of man, knowing full well upon which side the bread is buttered. If India would be unthinkable without the crows, an Indian garden without mynas could only be compared to roast lamb without mint sauce. The myna is not conly found throughout the Indian peninsula, but in every part of every station. Herein mynas and crows differ from almost every bird, except the sparrow. The others are not only localised in certain definite parts of the country, but in 
the tracts where they occur they are only seen here and there. Almost every garden has its own special avifauna. Quite a different set of birds live in adjoining compounds. Paradise fly-catchers abound in the garden next to mine, yet I do not remember ever having seen one in my yard; and it is the same with most birds, except crows and mynas, which are indiscriminate in their favours.

The myna, further, resembles the crow in that it has discovered that a mixed diet is the only truly scientific one. Insects and grubs form the staff of life of the myna ; these it supplements by a variety of food. Phil. Robinson has said that the myna has no wit. It is nevertheless intelligent enough to take advantage of the commotion which the progress of a cow or buffalo causes among the insects in the grass ; for it is fond of accompanying one of these quadrupeds in order to catch and devour the grasshoppers as they jump out of the cow's path-a leap from the frying-pan into the fire. Mynas spend most of the day on the ground looking for insects and grubs. They eat fruit and grain with avidity. These noisy birds are the first to find out when the wild cherries are ripe ; and many may be seen picking up the fallen grain in wheat-fields from which the crop has lately been removed. Faute de mieux mynas will hang about with the crows outside the kitchen, in hopes that scraps of rice or other food to their taste may be thrown out. Mynas make model husbands and wives. They invariably hunt in couples. Has anyone ever seen a solitary myna except in captivity? Where the husband goes, there is the wife sure to follow. "A pair of mynas," writes Phil. Robinson, "remind one of a Dutch burgher and his frau." Is it possible to pay them greater tribute than this?

Fortunately, it is only as examples of conjugal felicity that a pair of mynas resemble a Dutchman and his wife, for if they were like them in all respects, this article would never have been written, for, like the little nipper, I might say of such terribly respectable people " them I can't abide !" The myna is a bird of character. In his own way he is as vain 
as a peacock; he is obviously anxious to stand well in the estimation of man. Here it should be stated in the words of the framers of the Indian Penal Code, that in what follows, "the pronoun 'he' and its derivatives are used either of male or female;" I was almost saying " the greater includes the less," but for obvious reasons I refrain. A myna and his wife are so alike in outward appearance that it is as difficult to distinguish them as to say which of the weird figures found in children's Noah's Arks is intended for Noah and which for his wife. But this is a digression; as we were saying, the myna is most anxious to stand high in man's estimation. If you are very observant, you may chance to see once in a life-time a bedraggled myna-one who might have been making mud-pies; but no sooner does this dirty but sagacious bird catch sight of you than he stands at attention and is transformed into quite a respectable-looking creature.

The myna is a noisy bird, and here again one is obliged to join issue with Mr. Robinson, who says it is not, and declares that it "obtests against the chaunting of foolish litanies before the idols of his own conceit." It is true that I have never yet heard a myna sing a litany, but I have heard him emit every sound bar chanting. There seems to be no limit to the range of a myna's notes. Jerdon, of whom one always feels that he, like George Washington, could never tell a lie, so soberly and scientifically written are his books, says : "It has a great variety of notes, some of them pleasing and musical, others harsh; some have a resonant metallic sound." Perhaps the most pleasing note is that which it utters during flight. Undoubtedly, the harshest notes which the myna utters are sung at bed-time.

During the winter most of the mynas of our little station roost in a clump of bamboos which grow in the club compound. From September until April those bamboos are transformed into miniature Towers of Babel-miniature as regards height, but not as regards sound. The hundreds of mynas collected in them have an hour's shouting match 
every evening. Whether they act thus because they hold that lung exercise is conducive to sleep, or whether they are merely recounting the adventures of the day, I know not. Certain it is that all shout at once, and the result-pandemonium. I have never been to Saugor, but feel very sorry for those people who are stationed there, for in Jerdon it is written: "At Saugor all the parrakeets, mynas, crows, bee-eaters, \&c., of the neighbourhood, for some miles around, roost in company in a large grove of bamboos; and the deafening noises heard there from before sunset until dark, and from the first dawn of day until long after sunrise, give to the listener the idea of numberless noisy steam engines at work." May the parrots and crows of our station never strike up a friendship with the mynas. Nest-building and family cares cause the mynas to leave the bamboo-clumps during the hot weather, so that the members of the club are left in peace for a few months.

In every company certain birds act as watchmen or sentries, not only for their own species, but pro bono publico. In India the mynas have taken upon themselves this office. A sharp note from a myna, followed by the sudden hurried flight of all the birds near by, crows always excepted, is a sure indication that a hawk is hovering at no great distance. The search for food does not take up the whole of a myna's time. It seems to find ample opportunities for recreation. Some of its games are amusing to watch. In one of them five or six birds take part. One of the little company perches upon the branch of a tree, whereupon the remainder simultaneously try to jump on its back; the attempt ends in them all falling en masse for a distance of some five feet, when they recover themselves and fly off in different directions. Next, one of the flock alights, and the bird who happens to be nearest to him tries to hop on top of him, but the first bird slips away in time, flying off with the second myna in hot pursuit; and so the game continues.

Mynas are wont to build their nests under the eaves of houses, or in holes in walls or trees. Their nests, however, 
like those of crows, are not often seen. These birds, although they seem to take a positive delight in obtruding themselves on man, appear to object to his prying into their domestic arrangements, and so carefully conceal their nests.

Mynas are thirsty birds, and, like Englishmen, are very fond of cold baths. But the bathing of mynas is far too important a subject to be crowded into the tail-end of an article. It merits a monograph to itself. 


\section{$\mathrm{XI}$.}

\section{DUTCH NIGHTINGALES.}

THIS is not a discourse on nightingales that sing in

Holland, nor indeed on any bird. When I say that a Dutch nightingale is another name for a frog, AngloIndians, whose slumbers have often been disturbed by batrachian music, will at once appreciate the mild sarcasm expressed in the appellation. Frogsare interesting for the simple reason that they are the most unfortunate of animals. Cruel fate has endowed the frog with a body eminently fitted for dissection and for physiological experiment ; consequently the frog has become the martyr of science. Every embryo biologist, every budding medico, commences his studies by dissecting a frog or two. There is quite a scarcity of batrachians round some university towns. So greatly are these little amphibians in demand that some people make a living by catching them, the frogs thus caught being subjected to many indignities before they are put to death. There is in Great St. Andrew's St., Shaftesbury Avenue, London, a marvellous little shop well known to all zoologists, in which are to be found animals of every kind except elephants and giraffes. Frogs can be bought here alive at $2 d$. apiece. If the purchaser be inexperienced, he goes in unprepared and asks for a couple of frogs. Before he can say "Jack Robinson" two of these luckless amphibians are whipped out of a tank, and wrapped up alive in a neat brown paper parcel which he is expected to carry home in his pocket. It is true that the frogs do not appear to mind this treatment, for, on arriving at their destination, they hop out of the parcel quite gaily. The 
water frog, the rana esculenta that has the bad fortune to be born in France, runs the further risk of being cooked and eaten. Few Englishmen have been bold enough to try this form of diet, but those who have done so report that frogs are preferable to the most tender rabbit. In France the frog-catcher goes out at dusk, armed with a lantern and a long stick, at the end of which is attached a piece of red cloth. The light attracts the frogs to the place where the "fisherman" is standing. He then drops his cloth on to the surface of the water; and the greedy frogs bite at it, their teeth become entangled, and thus they fall an easy prey.

Some eighty species of frog are known, ranging in size from the great Louisiana Bellower to the diminutive treefrog. We in India, however, are chiefly interested in the grass frog, who keeps us awake by his perpetual croaking. This is doubtless his way of revenging himself on men for all the cruelties they practice on his brethren. We must, however, remember in justice to human beings that their rest was disturbed by frogs long before the scientist came upon the scene with his scalpel. For the classical poets are continually complaining of the frog. Ovid writes :-

"Qamvis sint sub aqua, sub aqua maledicere tentent,

Vox quoque jam rauca est, inflataque colla tumescunt."

While Horace complained on his way to Brundusium :" Avertunt somnos."

Mali culices, ranaeque palustres

What would he have written after a night spent in the Indian plains during the rains? It is said that in France in the good old days the nobles employed the peasants during the whole of the night in beating the ponds within earshot of the chateaux, with boughs of trees, to prevent the sleep of the lords and ladies being disturbed by their batrachian neighbours.

The frog spends the greater portion of his time in a quiescent state. In England he hibernates throughout the winter either in some damp hole or in the soft mud at the 
bottom of ponds and lakes. In India frogs are only active during the rains. Frogs are beasts of prey; they feed upon insects, caterpillars, worms and snails. They catch their victims in much the same way as lizards, by means of their protrusible tongue, which is attached by the front end to the lower jaw. Unlike lizards, frogs will only take their prey on the move ; a frog will not touch a dead fly or other insect. If they can obtain nothing else, frogs devour their neighbours. Besides man, the frog has many enemies; herons, crows, storks, pike and watersnakes are at one with the French in holding that frogs make excellent eating. Of great interest is the development of the frog. To watch the egg being transformed into the adult is to witness the acting of a great historical drama. Events which were spread over hundreds of thousands of years are crowded into a few short weeks. All animals in their development repeat more or less exactly the history of their race. In the case of the frog development takes place almost wholly outside the egg, so that it can be easily watched. Anyone may see a young frog climb up his own genealogical tree. A frog lays about five hundred eggs. These float on the surface of the water in masses which have the appearance of a tapioca pudding. Each egg consists of a dark-brown central part, the yolk, which is surtounded by a large amount of gelatinous matter, from which the developing tadpole may possibly derive some nourishment, but of which the chief object is to protect the embryo from changes in temperature. Take some of this spawn and place it in water in a glass pickle-jar and await developments. In India the tadpole soon hatches out, four days being usually sufficient for its incubation; whereas in cold England the process requires nearly a month. Probably the day after the spawn has been secured, the form of the young tadpole will be discernible in the middle of the albuminous matter. Next they will begin to move about inside the egg, and gradually force their way to the surface, where a terrific struggle for freedom takes place. The middle of the body 
is the first part to be set at liberty, the tadpole then adhering to the egg by head and tail in the form of a loop. At last perseverance is rewarded, and the young tadpole disentangles itself; it rests awhile after having accomplished this feat. The newly-hatched tadpole is about a third of an inch long and quite black. Protruding from the neck are two gills in the form of tufts. The tail is fringed by a soft fin. On the head are two suckers, by means of which it attaches itself to water plants or other objects. Tadpoles possess horny jaws by means of which they crop the water weeds upon which they feed and bite the urchins who fish in the ponds on Clapham Common. Consequently tadpoles are known as "toe-biters" to these fishermen. The tadpole is undoubtedly a more or less faithful copy of an ancestor of the frog.

Long ages ago, when flying reptiles were the denizens of the air, and deinosaurs and sea-serpents disported themselves in the ocean, there were no frogs. At that period the development stopped at the tadpole state. As time wore on, the conditions of amphibian life changed and with them the tadpoles. Their external gills became covered by a membrane and limbs appeared, so that they became able to survive when the pools in which they lived became temporarily dried up, just as the mud-fish are now able to. These periods of terrestrial existence grew longer in succeeding generations; meanwhile the legs increased in magnitude, the tail disappeared, and lungs developed, so that eventually the tadpole found itself changed into a frog. The original transformation of the tadpole into the frog occupied hundreds of thousands of years; in the developing frog the process is repeated in a few weeks. The lungs of the frog are still very imperfect, being simple sacs, and there are no respiratory movements of the chest. Breathing is in great part effected through the skin. For this purpose it is necessary that the integument should be damp; consequently whether frogs live on the ground or in trees, they are never found far from water. As yet the frog is but im- 
perfectly adapted to a terrestrial existence. The toad has advanced a stage further; water is not such an urgent necessity to him as to the frog. Thousands of years hence a race of frogs may be evolved which can live out of water for indefinite periods. If such be the case we must hope, for the sake of our descendants, that such frogs will have lost their power of croaking and no longer merit the name of "Dutch Nightingale." 


\section{XII.}

\section{A NATURALIST'S NOCTUARY.}

I AS a small boy, always thought that animals went to 1, sleep at sunset. This idea doubtless owed its origin in part to that beautiful, albeit unzoological, hymn which runs :-

"Now the darkness gathers,

Stars begin to peep,

Birds, and beasts, and flowers

Soon will be asleep."

A great many grown-up people share this view. It is true that they know that owls, rats, mice, and cats, to say nothing of certain other unmentionable animals, are busy during the night; but they probably think, if they ever give a thought to the subject, that such evil habits have arisen from the contact of those animals with degenerate man. Thus, J. K. Jerome writes of the guilty look on the face of the tom-cat as he sneaks home in the morning after a night spent on a roof of bad repute.

The delusion that all animals spend the night in sleep is, however, rapidly destroyed by a sojourn in this country. India is indeed the land of nocturnal animals. Not but that there are a great many of such creatures in other countries. The difference consists in this: in cold and temperate lands animals are nocturnal from necessity, whereas in hot places, such as India, they are noctivagous from preference. In England, for instance, fear of the enemies which prey upon them obliges many animals to seek their food by night: this means that the said enemies have no option but to do likewise and to turn night into day. Some 
flowers, even, have had to become nocturnal, since they depend upon moths for cross-fertilisation. Such flowers are invariably white, so as to be as conspicuous as possible, and they, at the same time, emit a powerful, but sweetlyfragrant, scent to allure their insect visitors. One cannot help feeling sorry for such plants and animals, for in England the majority of nights are cold and raw. How much better would it be for all parties-prey and devourer -if they would call a Geneva Convention or Hague Conference, and at it mutually bind themselves to give up their dissolute nocturnal habits. In India the matter is different. In most parts of the country, and during the greater portion of the year, the nights are the only time when existence is tolerable ; and even this is not true of some nights, for which one cannot say more than that they are less evil than the day. Small wonder then that many Indian animals are nocturnal from choice. The majority of those whose habits are diurnal take a siesta during the middle of the day, when the sun attains its maximum power. Such creatures are nocturnal in the sense that babies are. Having spent the major portion of the day in slumber, they cannot be expected to sleep throughout the night, and so they busy themselves in disturbing the repose of the human being who does wish to pass the night in sleep.

It is not an easy matter to draw a hard-and-fast line between nocturnal animals and those who seek their food during the day. Many creatures, such as the tiger, the elephant, and the bear, may be said to be semi-nocturnal, since they sleep during the middle of the day, and make up for this by being active during part of the night. Still more nocturnal in their habits are the leopards and junglecats, which are but rarely seen abroad during the day. It is on account of this night-roving propensity of so many beasts of prey, to which must be added the existence of twolegged cattle-lifters, that natives so regularly drive their cattle into the byre at sunset. One might pass through half India by night without coming across a single cow 
or buffalo, except stolen ones. This procedure of being locked up for the night must seem strange to the cattle, for they are naturally nocturnal animals, as any one can verify for himself by taking a moonlight walk through some pasture lands in England. The cattle will almost invariably be found to be feeding. But if Indian cattle are not allowed to indulge in their nocturnal predilections, the rest of the fauna makes ample amends. No sooner have the crows ceased to caw and the flies desisted from their teasing, than the jackals begin to howl, and the mosquitos to commence their campaign.

I do not feel competent to decide to which animal should be given the title of champion-maker-of-the-nighthideous. I have given much thought to the matter, but so many animals are able to advance such weighty claims that I consider that the matter should remain in abeyance until a plebiscite of every Anglo-Indian be taken. The jackals would be well in the running, for they, like the poor, are always with us. Changes of temperature apparently have no effect on them; their yells are equally energetic with the thermometer at zero or dancing about in the nineties. In the day time the jackal is a quiet animal. He spends most of it in sleep, and when he is awake and moving he does so silently and alone or with but one friend. At night, however, they act on the principle that " union is strength," and collect together in great packs of which every member is obliged to try to shout down all the rest without an interval until morning light appears. The only weak point in the jackal's claim to the title is that he can be only in one place at a time. If each jackal could contrive to be simultaneously in two hundred places, I should have no hesitation in awarding him the night-disturbing prize. As it is, the claims of other creatures must be considered.

The frogs on account of their raucous croakings are powerful competitors. There are so many of them that they do not need to be in several places at once. The flaw 
in their claim is their lack of staying power. They are magnificent while they last. Has not the poet Horace immortalised their vocal efforts? But they are of short duration. Their inspiration ceases with the rain. Scarce has the last monsoon cloud passed away, when they betake themselves to their underground quarters, there to sleep until once again Jupiter Pluvius reigns supreme. (N.B. -This is not a pun.)

The same weakness is apparent in the claims of the owls. These creatures take up a strategical position in a hole in the tree nearest to the bungalow, and from this point of vantage give vent to sounds compared to which the voice of the jackal is "grateful and comforting." Owls, however, do not care to make themselves too cheap, lest their talents, becoming common-place, should not receive the amount of appreciation they deserve. Hence by the time the first froggie to emerge is beginning to croak, most of them are far away to the north, giving the inhabitants of a serener clime the benefit of their voices.

The mosquito is a most dangerous competitor for the prize. He disdains the vulgar yell of the jackal, the coarse croak of the frog, and the weird screech of the owl. He emits a gentle note in a high key which sets one's teeth on edge. This he does unceasingly throughout the night. He never tires. At 4 a.m. he is as fresh as he was at 6 p.m. the night before. Although he prefers a damp heat, he is apparently able to knock along very comfortably in a dry or cold climate. I have seen mosquitos in January in the hills when the temperature at night is many degrees below freezing point.

The cricket makes a bold bid for the championship, but I fear that the competition is too hot for him. In a country such as England, crickets are well in the running, provided they do not go to London, where the cats on the roof are generally held to be invincible. In India, however, the feeble voice of the cricket is drowned by those of the other competitors. 
The pariah dogs would in all probability win the championship for disturbing sleep, but for the fact that they are sorely handicapped by the distance which usually intervenes between the site of the European quarters and that of the native city. I have often lain awake at night and listened to the distant barking of the dogs; never have two consecutive minutes and rarely as much as ten seconds passed without a dog either barking, yelping, or howling. The pariah dogs give vent to successive waves of sound. First there is awful discord made up of barking, yapping, yelling, howling, and yelping; this gradually diminishes, until the barking of only one dog is heard; then even he ceases for two seconds. Next another bark is heard which seems to arouse half the dogs in the city, for the babel again commences and lasts for fully five minutes before the volume of sound again diminishes. Thus the night noise of the pariah dogs is an undulation of which the ascending limb is short and sharp, while the descending one is long and drawn out.

Perhaps the organism which most deserves the prize for making the night hideous is the Indian cultivator. $\mathrm{He}$ is, I am aware, a hard-worked man, and I like him; but I do not admire his methods; to me they seem crude and primitive. Could he not have found some device for keeping wild boars out of his sugar-cane field, other than that of shouting with might and main the livelong night? Surely he deserves the prize ; it is, I trow, no mean feat to toil all day and shout all night!

But stay, I have forgotten the peacock. According to the Italians this bird " hath the plumage of an angel, the voice of a devil and the belly of a thief." For the truth of the two first assertions I can vouch; of the third I am only able to say that no peacock has ever stolen anything of mine except sleep, which is not a subject of larceny. In order to hear the peacock at his best, it is necessary to sleep in a bagh surrounded by temples, tanks, fakirs, et hoc genus omne. While listening to the efforts of the gorgeous 
bird one makes up one's mind to award him the prize in the philharmonic contest, but then one feels that the other competitors would object, with some show of reason, that the peacock is disqualified, since, while they bring their music to one's residence, it is usually necessary to leave the bungalow in order to hear the peacock. He shuns the habitations of the unholy.

Before leaving the noisy members of the fauna of the night, the koel should be mentioned; for it, although not a night bird, has often so much to say that it is unable to get it all in during the day and consequently talks during much of the night.

We must now give the quieter animals their innings. Midway between the quiet and noisy noctivagous animals comes the scorpion. This little creature makes no noise itself, but often causes others to do so. During the day it lies up in the clefts of rocks, in old boots, or other convenient places, and as the shades of night steal over the land it creeps forth, with tail jauntily cocked over its head, seeking whom it may devour. Its prey consists chiefly of insects, which it stings to death and then demolishes at its leisure; these poor creatures, having no voice to speak of, perish without our being aware of the tragedy that is taking place within a few feet of us. It is when a scorpion bites a dog or the chaukidar that one hears sound in its most concentrated and virulent form.

The innings of the silent brethren of the night will, perforce, be very short, for want of space prevents anything being said of the snakes, which, like other wicked creatures, love the darkness; of the black-beetles which gaily career over the floor the moment the light is extinguished; of the busy ants, who seem to work harder, if that be possible, during the night, than they did during the day; of the termites, which in one night will construct a tunnel two yards long; of the mighty crowd of insects which merrily dance round each lamp; of the lizard who devours those insects until he looks as though he would suffer the 
sad fate of the English king who was fond of lampreys; of the rats and mice which steal our food; of the musk-rat which would seem to have discovered a method of forcing liquid through cork or glass, since are there not people who solemnly speak of "musk-ratty" wine; or of the uncanny bats which move so silently. Far less will space permit us to wander to the forests to seek the flying squirrels, or to the river swamps to watch the gambols of the rhinoceros. It must suffice to say that these and many others belong to the fauna which revels in the shades of night. 


\section{XIII.}

\section{THE MALARIA MIDDLEMAN.}

THE mosquito has fallen upon evil days. Time was when man was its best friend. In the unscientific period of the nineteenth century men provided free meals for the little insect, and made, in every available place, nurseries of water in which the baby anopheles could disport themselves to their heart's content. Those were indeed halcyon days for the mosquito. They have departed, no more to return. Tempora mutantur et nos mutamur in illis. Science, one day, pointed her finger at the mosquito; she indicated him as the carrier of malaria. That was the crisis in his history. Those who had before regarded him with easy indifference suddenly became his ruthless enemies. And now fierce is the war which the votaries of science are waging against the anopheles-a war of extermination. In some parts of the world theirs is already the victory. It is said that the mosquito population of Havana has been reduced by more than 90 per cent. owing to the exertions of the sanitary authorities.

Recent research, however, has shown that there are mosquitos and mosquitos. All are not conveyors of malaria; some carry worse things. Culex, for instance, does not take any part in the dissemination of the malaria organism; it finds its work cut out in carrying from person to person yellow fever and other horrible diseases. These latter, however, are not among the ills to which flesh is heir in India; hence we Anglo-Indians look upon the culex as a comparatively harmless creature. Our bete noir is the nasty anopheles, who sucks our blood and in return injects the malaria germs into us. The real cause of malarial fever 
is a little animal organism that enters man's blood, and there grows and multiplies exceedingly, as is the wont of such objectionable animals. While it is enjoying life in the blood of its victim, he is suffering from fever. Now up comes an anopheles mosquito who makes a meal at the expense of the fever-stricken man, and imbibes a goodly number of the parasites, which undergo further changes in the body of their new "host"- such is the term that the facetious scientist applies to the unwilling victim of the parasite! The malaria organism then bores into the tissues of the mosquito. It is a matter for human satisfaction that the process must be a painful one, at least for the mosquito. When it has become comfortably esconced in the tissues of the insect, the malarial germ reaches maturity and produces a fine brood of young ones. These soon discover that the poison gland of the mosquito is an agreeable residence. They do not remain there long, for they are injected into the blood of the mosquito's next victim; then the fat is in the fire. He gets fever; and thus the cycle recommences.

The malaria parasite, therefore, requires two hosts in order to complete its life-history. If it fails to meet these it pines away and dies. There are quite a number of parasites to the existence of which two hosts are absolutely necessary. The tapeworm and the trichina are well-known examples. The latter is the cause of "measly" pork. The pig is indeed the parasites' happy hunting ground. Why it is that the anopheles mosquito is the only one which will serve as the "intermediate host" for the malaria organism is not quite clear. Possibly the culex prefers the blood plain, without the malaria sauce. More probably the climate of the interior of a culex is one which disagrees with the constitution of the malaria parasite. Be this as it may, one fact appears to be fairly established, and that is, mosquitos of the genus culex do not act as carriers of malaria, while anopheles do. It therefore becomes important that man should be able readily to distinguish between the two species. The larva or baby-forms of culex have acquired 
the foolish habit of floating in the water head downwards, with the extremity of the tail touching the surface of the water; but when disturbed they at once wriggle to the bottom; they have no limbs, so must, perforce, wriggle. The highly offensive anopheles larva floats on the surface of the water like a piece of wood; and when annoyed wriggles along the surface of the water. In the adult forms the differences are more marked. The wings of anopheles are spotted, those of culex are plain. The body of the former is slim and elegant, while that of the less-favoured culex has been described as coarse. When settled on the wall, or other object, anopheles assumes a jaunty attitude. He cocks his tail up into the air in the most haughty manner; while the culex keeps his caudal appendage parallel with the surface on which he is resting-a humble posture. As they sit side by side they remind one of the Pharisee and the Publican.

The mosquito is now attracting so much attention that he bids fair to rival the Colorado Beetle in this respect. Fresh books dealing with the habits of mosquitos, and the methods of destroying them are continually appearing. Expeditions of experts frequently set out for fever-stricken portions of the earth in order to study the doings of the insect. Conventions meet to discuss the ways of fighting him. Governments publish the results of the labours of the scientists. Medical men wage war against the carrier of malaria with more or less vigour according to their disposition. We have a Civil Surgeon on whom the sight of a mosquito has the same effect as that of a red rag on a bull. In vain he preaches to us, urging us to close our tanks and let the flowers in our gardens perish. We are an obstinate and stiff-necked people. He therefore sends round once a week a man armed with a kerosene oil tin; the oil from this is spread-one ounce to the square yard is the dose-over the surface of every puddle, pool or tank in the neighbourhood of the station. The layer of oil smothers the mosquito larvæ. Since the abolition of tanks, ditches, 
ponds and puddles is a counsel of perfection, at any rate in India, it is useful to know that fish readily eat anopheles larvæ; hence, if a sheet of water cannot be abolished, stock it with fish.

It is, however, to two Cambridge dons-Dr. Nuttall and Mr. Shipley - that we are indebted for the latest discovery concerning mosquitos. They have an eye for colour. Nay more, the artistic temperament appears to be developed in them, since they prefer some colours to others. Navy blue is a colour after the mosquito's own heart; red is a good second. The colour that mosquitos-to use an expressive vulgarism - "can't abide," is khaki. This interesting fact was discovered by taking a number of boxes lined with cloth of different colours. These boxes were without lids. They were placed in the sunlight in a room in which mosquitos were bred in considerable quantities. Bananas, or, in default of these, figs, form the diet most palatable to the mosquito. The positions of these boxes were frequently changed, so that there should be given a fair field, and no favour shown, to every box. The mosquitos were then left to their own devices and desires. And every day the number of mosquitos which had settled in each box was counted. The experiment lasted seventeen days. Navy blue was the favourite colour. During the seventeen days 108 mosquitos settled in it. Dark red was a fair second with 90 mosquitos. Not a single mosquito settled in the box of which the lining was "pale yellow, almost the colour of khaki." Next to the khaki the most unpopular colours were white, ochre, light blue and pale green. Mosquitos obviously prefer dark colours to light.

These experiments can easily be tested by the man in the street-provided the street in which he lives contains mosquitos-by his hanging up, side by side, a khaki and a navy-blue coat, and observing the number of mosquitos which settle on each. So conclusive is this experiment considered that the ever-vigilant Americans have ordered that in malarial regions the regulation army navy-blue 
shirt is to be replaced by a khaki one. We shall soon hear of the Yankee soldiers being dyed khaki in order to baffle both the mosquito and the enemy. The policy of dyeing oneself khaki is not likely to recommend itself to many of us. Which is the lesser evil, to run the risk of fever or to go through life with a khaki face, is a question which each may answer for himself. Personally, I plump for the fever and for the scientific, but difficult, policy of doing away with the middleman who busies himself in carrying fever from person to person. Political economists assure us that the middleman is an injurious anachronism. Let us, then, abolish him wherever we can. 


\section{XIV.}

\section{MAMMALS OF THE AIR.}

$\mathrm{B}^{\mathrm{ATS}}$ are weird, dark, and dingy creatures, and there are none like unto them. Distributed almost the whole world over, they are especially plentiful in India ; yet we have learned but little of their habits. Our knowledge of most species is limited to the fact that they sleep during the day in caverns, temples, outhouses and other secluded spots, from which they emerge with the shades of night to either prey upon insects or rob trees of their fruit, according as they are insectivorous or frugivorous. Batland offers a great field of research for some leisured man, but, alas! in this stern, work-a-day country where is such an individual to be found? Bats are unique among mammals in the possession of wings. It is one of the pranks of Dame Nature that she should give those emblems of purity to animals whose bodies are covered with vermin, and whose habits are disgusting to a degree. Possibly it is on account of these latter characteristics, possibly on account of the strangely silent manner in which bats, like evil spirits, flit about after nightfall, that they inspire me with an unconquerable repugnance. There are people who cannot tolerate a black cat in the room with them. This is a time-honoured prejudice, nevertheless the black cat has no terrors for me ; in my case the bat takes the place of the cat. The chief indoor amusement of all bats seems to consist in testing the acuteness of their senses by ascertaining how near they can fly to the head and face of a human being, without actual contact. This is a game, which, if we may believe Fenimore Cooper, Red Indians are fond of playing on their captives with their tomahawks. That kind of thing is 
all very well in the Far West, bui it seems out of place in the placid East. When one is captured by red-skins, one should anticipate a lively time, but to be thus treated in India, after a hard day's work while the mercury in the thermometer was oscillating among the nineties, is unseemly.

Accordingly, I make a point of casting into the outer darkness any bat that is imprudent enough to invade my domain. Now the eviction of an Irish tenant is mere child's play as compared with the ejection of an obnoxious bat from a lighted room at night. The tactics most approved by the highest authorities are the opening of the door, and the taking of a stout bath-towel, then to try by gentle flickings to persuade the bat to leave the room. Bats are, as a rule, not amenable to reason, so there is no help for it but to violate the canons of the Society for the Prevention of Cruelty to Animals and fell the bat to the ground with a vigorous stroke of the towel, and then pick it up with the tongs and cast it forth.

Of course, I am fully aware that bats, like Red Indians when playing with their tomahawks, never actually touch their victim. To avoid this, considerable skill must in each case be displayed. Indeed, the sense organs of the bat are unsurpassed for delicacy. This has been proved by Spallanzani's classical experiment. He deprived some bats of their eyes, ears, and noses, and then set the maimed creatures free in a room across which threads were stretched in all directions. The bats flew about freely, avoiding these obstacles with the same ease that a London telegraph boy threads his way through a crowded thoroughfare. The bats were able to do this on account of the sensitiveness of their wings, which in this respect resemble the antennæ of insects.

Bats fall into three classes, according to the food upon which they subsist. There are the fruit-eaters ; those which feed upon insects; and the vampires, or those bats which suck the blood of animals. Let us give these last the first innings. It is usually written in books on Natural History that blood-sucking bats are found only in South America. 
This is not strictly true, for there occurs in India a bat, called Megaderma lyra, or the Indian vampire, which undoubtedly preys upon small mammals. Blyth saw this creature devouring another bat. It commenced by seizing its victim behind the ear, and then calmly proceeded to suck its blood during flight. It, however, is not content with mere blood-sucking; it devours its victims. In the evenings it may sometimes be heard crunching the bones of frogs, which appear to form its favourite diet. It will not attack toads, the nasty secretion from their skin rendering them immune. This creature is probably an insectivorous bat which has recently taken to bigger game.

South America is the true home of the vampires. These attack men, horses, and cattle. The tip of the toe is the portion of the human frame which they usually attack. Whether this is because it is the most accessible part of a man when in a recumbent posture, or whether there is, in the eyes of the bat, any special virtue in blood drawn from this region, we have no means of ascertaining. Nor is it known for certain by what means the animal bores the hole. Some declare that it is the tip of the tongue that does the trick, others put their money on the canine teeth. These persons impose on our credulity by asserting that when the tip of the tooth is dug into the victim, the hole is amplified by the bat's turning on the tooth as on a pivot. Be this as it may, the wound inflicted is a small round one, which bleeds profusely, so that some skill is required in order to staunch the blood-flow. Vampire bats are therefore but clumsy exponents of the art of blood sucking, and might with advantage take lessons from the gentle mosquito, or even from the less gentle village bania. The after effects of the bite of the vampire are most disagreeable, so that we may well be thankful that the Indian vampire confines its attention to such small fry as the frogs.

Insect-eating bats are the only kind found in England, and comprise the great majority of Indian species. Wellknown examples of such are the horse-shoe bats and the 
leaf-nosed bats, so common in the Himalayas. They lie up during the day, coming out at sundown to catch beetles, flies, and other insects. Many bats lay themselves out more specially to catch one kind of insect ; thus the common yellow bat goes for " white ants," while the pipistrelle feeds chiefly on gnats. To this difference in prey we may attribute the different habits of flight. Some bats move faster than others, some turn exceedingly rapidly, some fly high up in the air, others skim the ground, and a few hunt over the surface of water. During the day all these bats roost in any dark place. Some ancient temples literally swarm with them, and if one enters such a temple during the day the dome is seen to be black with bats, which make a pretence of sleeping. In reality, each one spends the major portion of the day trying to make his neighbour lose his equilibrium. When this happens, the injured neighbour makes a great noise and flitters about for a little, and then proceeds to disturb some other bat who is trying to snatch a few moments of sleep, and so the noise continues all day; but in the evening the bats become silent and issue forth to seek food. Considering the number of insects that are abroad during the day, it seems wonderful that all species of bat are so completely nocturnal. I have often thought what a good time a bat would have if he were bold enough to leave his quarrelsome companions and look for insects during the day. There must be some good reason why no bats have become diurnal, although what this reason may be, 1 know not; it can hardly be the fear of hawks and other birds of prey, for bats are rapid fliers and are surely able to look after themselves as well as birds are.

Finally, we have to consider fruit-eating bats. Greedy brutes these are. The amount of fruit that one individual can put away is appalling. The bat eats with its head downwards, using its claws as forks, taking in disgustingly large mouthfuls and cramming in so much food at once that the cheeks become quite distended. Writing of the common Indian fruit-bat, popularly known as the "flying 
fox," Jerdon says :- " During the day they roost on trees generally in large colonies. Many hundreds often occupy a single tree, to which they invariably resort if not driven away. Towards sunset they begin to get restless, move about along the branches, and by ones and twos fly off for their nightly rounds. If water is at hand-a tank, a river, or the sea-they fly cautiously down and touch the water, but I could not ascertain if they took a sip or merely dipped part of their bodies in. They fly vast distances occasionally to such trees as happen to be in fruit. They are fond of most garden fruit (except oranges, \&c.), also the neem, jamoon, ber, and various figs. About the early dawn they return from their hunting ground." While preparing to roost in the usual tree, as often as not a tamarind, the amount of wrangling that goes on is terrible. I have already described the behaviour of bats in a temple. In a tree the squabbling is a thousand times worse. The bats appear to have some slight reverence for the sanctity of the temple, but in the tree they cast off all restraint. They bite each other unmercifully, and use the long claw of the thumb as though it were a fork and their neighbour a potato, "shrieking and cackling" the whole time, but they do eventually settle down, which is more than the bats in the temple ever seem to.

These "flying foxes" are common throughout India, Burma, and Ceylon. In Calcutta they are to be seen in long strings going to and fro from their roosting place. At Rangoon, McMaster, with the help of a friend, counted as many as six hundred passing in five minutes; while Sir J. F. Tennant tells us that in Ceylon, near Kandy, were some india-rubber trees which the bats of the neighbourhood evidently considered fashionable, for on these they " used to assemble in such prodigious number that large boughs would not infrequently give way beneath the accumulated weight of the flock." Such is the grip of fashion, even on bats. The "flying fox," like most bats, gives rise to but one young at a birth. This hangs on to its mother's fur, so 
that she takes it along with her everywhere until it is about two months old. On account of their diet the fruiteating bats are easier to keep in captivity than are insectivorous ones. Horrible to relate, some natives eat the flesh of the bat, and a few bold spirits among Europeans have sampled it, and declare that the flesh is " well flavoured and delicate." I am prepared to accept their verdict without putting it to the test. 


\section{XV.}

\section{THE KING-CROW.}

INDIA is the land of interesting birds. For beauty of song its avi-fauna must yield the palm to that of England, while its birds cannot vie in brilliance of plumage with the feathered inhabitants of some tropical countries; but in all other respects Indian birds are unequalled. There is more genuine amusement to be derived from watching half a dozen Indian crows for an afternoon than from a month's observation of birds in most other countries. If any one doubt this, let him read any number of books on the birds of other countries, and then decide whether, as regards character, there exist any birds in the same street with Indian crows and mynas. The truth is that in India a man is forced to be a naturalist in spite of himself. The birds and beasts simply refuse to be ignored. It is a physical impossibility to avoid them. Often they compel one to watch them when one is least inclined to do so. To take an example. Quite recently I arrived at a $d \hat{a} k$ bungalow late on a very hot night. My bed was placed on the verandah. Shortly after dawn I was awakened by a tremendous commotion. The cause of it was this. A pair of mynas had built their nest in one of the deep recesses between the beams under the roof of the bungalow. The bearer had placed my bed in the direct line of flight from the outside to the nest. Now the myna is not a great flier. A swift can enter its nest at the most impossible angles. Not so a myna. He can only approach in a straight line. I had thus unwittingly cut off the usual passage to the nest, and the parent birds were making most frantic efforts to enter it at an angle. In this 
they ignominiously failed. After a tremendous amount of fluttering of the wings, the birds were obliged again to alight on the ground without having given to their offspring the morsels they had secured for them. Sharp and shrill were the cries of the disappointed parent birds, and heartrending the notes of the still more disappointed youngsters, who naturally resented this unaccountable neglect of their parents. However, benevolence is not my characteristic feature when awakened at 4 a.m., on a hot morning after a restless night. I did not move the bed, but tried to get some more sleep. After a time the mynas grew still more excited, and, sleep seeming to be out of the question, I arose to see if I could discover any fresh disturbing element. A dire tragedy had been enacted. There before my eyes lay a young myna that had fallen out of the warm nest on to the cold stone floor of the verandah. Round the unfortunate youngster danced the parents in a state of great excitement. The young bird must have been newly hatched, for its body could not boast of a feather, while the eyes were still closed. A young myna is not a pretty sight. It is all stomach and beak. The former organ would do honour to any alderman, while the latter is at least ten sizes too big for the rest of the body, the stomach always excepted.

In young birds nature sacrifices beauty to utility without scruple. That great ugly gaping beak is very necessary to enable parents to feed the young birds. I lifted the young myna back into the nest amidst the frantic screams of the parents. Thus did I find myself before 5 a.m., not only engaged in a natural history study, but even driven to active interference in the domestic matters of a family of mynas!

But it is time we were speaking of the subject of this article; otherwise it will be likened to a lady's letter in which all the news is to be found in the postscript. The King-Crow is one of those " bold bad " birds so common in India, and which make its fauna so fascinating a study. Needless to say it is not a crow, for in India we seem to take 
a positive pride in miscalling the birds and beasts which surround us. So far as I know the only reasons for calling Dicrurus macrocercus the King-Crow are, that he spends great part of his life in chasing crows proper, that he is black from head to tail, and that the latter appendage is forked; this is possibly regarded as a sign of royalty. The tail is certainly the feature of the King-Crow. When seen sitting on a telegraph wire or on the bare branch of a tree -the bird's favourite positions - the tail appears to be too long for the owner, and gives it a fragile appearance; while if the bird be seated on a branch covered with foliage, the tail appears to be an unmitigated nuisance to its possessor. This opinion, however, is soon changed when the bird is seen at work in the air. Insects form its chief food. No six-legged creature comes amiss to it, not even a bee or a wasp. It takes up a position on the top of a tree, bush, or other eminence, until it catches sight of an insect, when it sallies forth and seizes it. The bird's gymnastic performances in the air are marvellous, its forked tail is a perfect steering apparatus. It is futile to attempt to describe the aerial flights of the bird especially when everyone in India may see them for himself if he only keep his eyes open. Like the crow proper, this bird spends much of its time on the backs of cattle, looking for insects. India is not the only country in which birds have acquired this habit. The jackdaw and magpie are said to perform a similar service for English sheep and cows, but if we may believe the British farmer, the jackdaw and magpie are far less skilled operators, for their beaks often give the cattle nasty wounds.

Mr. Hudson, in his most recent book, maintains that there is some one occasion when every bird is seen at its very best. This psychological moment for the King-Crow is when he is chasing a common or garden crow. Like the Englishman, the King-Crow holds that his house is his castle. But the sagacious bird goes farther than the Englishman; he puts a wide interpretation on the meaning of the word " house," making it include not only the nest, but 
the whole tree in which the nest is built. He has the courage of his convictions. He spends the greater part of his life in living up to them. He will on no account allow any bad character to enter his domain. Crows, hawks, kites, $e t$ hoc genus omne come under the category of "bad characters." Now, crows are as inquisitive as they are mischievous, hence they make it a point of honour to investigate a King-Crow's nest whenever they see one. The investigation is apt to be hurried. While the crow is yet afar off, the brave little drongo sallies forth to meet him. As a rule the flight of the latter is not particularly rapid; when, however, he is on the track of a crow he flies like greased lightning. The crow at once decides to discontinue the investigation. He turns tail, with the King-Crow and his spouse in hot pursuit. These try to get above the fugitive crow and peck at its back and tail. They do not often get a blow home, although I have seen them do so. Mr. Phillips, who tells some tall stories of King-Crows-stories of which any fisherman might be proud-states that he has seen the King-Crow fix on the back of a hawk with claws and beak for some seconds. The wonder is that the crow does not turn round and face its adversary and then demolish him. Possibly it is cowardice that prevents the crow from so doing, more probably the crow is a ware that the little bird is too fast for him.

Some rude people have been known to call the KingCrow the Scotch Nightingale, which is unkind to both the hardy Scot and the gallant drongo. The cry of the latter is at least cheerful, and he makes no pretence of being a fine songster. Action, not words, is his motto. The KingCrow despises the enervating influence of a comfortable nest. A rough structure composed of twigs and roots, usually innocent of any lining, placed in the fork of a branch forms his castle. In this Spartan abode are reared up the young hopefuls, who are destined to pursue many a crow. If we may believe Mr. Phillips, the King-Crow is as crafty as he is brave. On one occasion this bird coveted a certain 
locust which another bird was chasing. After making several futile dashes at the locust, the King-Crow gave forth the cry of alarm it emits when a hawk is coming. The other bird fled for its life, while the King-Crow proceeded to demolish the locust. 


\section{XVI.}

\section{THE HOME OF THE SWIFT.}

INASMUCH as this article treats of that most hackneyed subject-birds' nests-it is only fitting that I should lead off with an apology. I am aware that the architecture of birds is a theme which Yankee editors would apostrophise as "a bit hoary and bald-headed." Nothing but a sense of justice, nothing short of a desire to rescue the subject from the evil plight into which it has fallen, induces me to pen what follows. To attract the attention of poets and moralists is the worst calamity that can befall a scientific subject, for it then becomes mutilated for the sake of art, and distorted to suit the ends of the teacher of morals. Just as the most beautiful tune becomes debased by falling into the hands of the organ-grinder, so has that most interesting subject-avine architecture-become stale and insipid under the treatment of those who delight to descant in extravagant language on the wonders of the subject-wonders that, as often as not, happen to be non-existent. Watch carefully a pair of swifts at work on their nest and you will be astonished, not at the marvellous intelligence of the birds, but at the many imperfections and limitations of their instinct.

Considering the intensity of the struggle for existence, it is surprising how often the nest-building instinct of birds is at fault. For example, a pair of swallows build a nest in a place inconvenient to a human being, with the result that the latter sweeps away the offending structure. Instead of profiting by experience and avoiding the dangerous site, the foolish birds will, as likely as not, try to construct a new nest on the ruins of the old, Then, again, the average 
nest is a very unsafe nursery for young birds. Every year countless numbers tumble out and fall victims to the evervigilant crows; yet the parent birds make no attempt to render the nest more safe. In Kumaun the house-swift (cypselus affinis) exists in greater numbers than even the ubiquitous crow. The nests of these active little birds are to be found under the eaves of almost every native tenement ; while the verandahs of the majority of $d \hat{a} k$ bungalows form veritable swifteries, if I may coin a word. It has been my lot to spend many days in dâk bungalows among the Kumaun hills, where the "shivering scream" of the houseswift is heard unceasingly throughout the day, and very frequently during the night; it is for this reason that I have taken as a type the nest of the swift. During June and July, nest-building was in active progress ; and now families of young swifts are the order of the day.

The nest of the common Indian house-swift is so familiar that it seems superfluous to describe it. It is built of rubbish. The bird collects straw, grass, feathers, etc., and by means of its sticky saliva glues them to one another and to the roof under which the nest is placed. The principle upon which swifts and other members of the swallow tribe construct their nests differs considerably from that adopted by the great majority of birds. The usual method is to build the nest on some foundation which forms a base, such as the ground, a hole in a wall or a tree, or a forked branch. The swift finds ready-made a roof and a couple of walls, and then proceeds to construct the floor and the remaining walls of his home. To the unsophisticated human being it is a mystery how the swift ever manages to make a start on its nest, there being nothing in the shape of a ledge upon which the bird can rest while at work. This does not trouble the swift. Its claws are simply hooks by means of which it is able to hang on to any vertical surface. This is done without the least effort. Indeed, a swift rests by hanging on to a wall in this manner. It never sits upon the ground as other birds do: those hook-like claws which 
enable it to hang on to a smooth wall prevent it from resting on a flat horizontal surface. Therefore a swift, from the moment it leaves the nest until the time it returns, is constantly on the wing; to enable it to endure such prolonged flights it is provided with most powerful pinions; hence Richard Jefferies calls the swift "the black albatross of our skies." "Like the albatross that floats over the ocean and sleeps on the wing, the swift's scimitarlike pinions are careless of repose." These birds, however, do rest at times, and one or two swifts in every colony may usually be seen hanging on to the wall close under the roof and looking very much like bats.

The beginning of the nest, then, offers no difficulty to the swift. The bird flies to the selected site, carrying far back in the angle of the beak a feather or other material for the nest. It presses this with its beak against the rafter and holds it there until the saliva it secretes has had time to harden and firmly fix the object-a process which takes about five minutes. The swift then goes off in search of other material which it affixes in the same way, and continues to work in this fashion until the nest is finished. I have been struck by the slowness with which the work proceeds. In this respect a swift would do credit to any Trade Union; he would, however, be disqualified for membership on account of the long hours that he works. It is not laziness on the part of the swift which causes progress to be slow ; it is stupidity. In this respect the bird differs from the British workman. I have never been able to remain sufficiently long in one bungalow to observe the whole process of nest construction from start to finish,-but I should fix three weeks as the minimum time required by a pair of swifts for the building of a nest.

I once timed a couple of swifts at work. At 8-13 a.m. one bird left the half-built nest, the other being away; it returned at 8-57 followed by the other bird at 9-2. At 9-5 both birds left the nest, the former having added a feather and the latter nothing. Neither bird had returned to the nest 
by 9-35, when I left the verandah until 10-9. At 10-30 one of the birds came to the nest, but carried nothing in its beak; it stayed about one minute in the nest. Throughout the day the birds returned at intervals of about 45 minutes, as often as not without bringing any building material. It is, therefore, safe to assert that on an average each bird does not add more than twenty feathers, etc., to the nest in the day, although they work from sunrise to sunset.

When we consider the multifarious nature of the objects that are utilised as building materials for the nest, the slow rate at which the work proceeds becomes the more remarkable. In the present instance there were quantities of straw and pieces of dead grass strewn in the hedge and on the ground in front of the bungalow ; but the swifts passed these by unnoticed. It is true that the birds had to find food, and when one's diet consists of flies, it takes some little time to obtain a good square meal. The search for food, however, cannot occupy more than a fraction of the day; for if a swift required more time to secure its food how could it manage later on both to feed itself and to procure meals for its young? We are, therefore, driven to conclude that it is nothing but lack of intelligence which makes the swift so slow a workman. It may possibly be asserted that the swift is an exceptionally stupid bird. I submit that this is not the case. The jackdaw is generally admitted to be one of the cleverest of the fowls of the air. At Wells Cathedral hundreds of daws build nests behind the stone statues which stand in niches in the Cathedral wall. The cavities are such that no sticks of which the length exceeds eighteen inches can be used in the construction of the nest, yet the daws continually bring up sticks as long as seven. feet. These are dropped, as are many of a suitable length, during the efforts of the bird to bring them into the niches. The sticks which the daws thus let fall have to be cleared away every day or they would soon block up the entrance to the Cathedral. No one, with the solitary exception of Mr. Hudson, has ever seen one of these birds attempt to pick up 
a stick it has dropped. The stupid daws will go miles in search of materials for the nest when there is a great pile of these at the foot of the Cathedral.

Since the exception observed by Mr. Hudson serves to prove the rule that, judged by human standards, birds have but little intelligence, I will give it in his own words. "One morning at Wells, as I stood on the Cathedral green, watching the birds at their work, I witnessed a rare and curious scene-one amazing to an ornithologist. A bird dropped a stick-an incident that occurred a dozen times or oftener any minute at that busy time; but in this instance the bird had no sooner let the stick fall than he rushed down after it to attempt its recovery ; just as one may see a sparrow drop a feather or straw, and then dart down after it and often recover it before it touches the ground. The heavy stick fell straight and fast on to the pile of sticks already lying on the pavement, and instantly the daw was down and had it in his beak, and thereupon laboriously flew up to his nesting-place, which was forty to fifty feet high. At the moment that he rushed down after the falling stick two other daws that happened to be standing on ledges above dropped down after him, and copied his action by each picking up a stick and flying with it to their nests. Other daws followed suit, and in a few minutes there was a stream of descending and ascending daws at that spot, every ascending bird with a stick in his beak. It was curious to see that although sticks were lying in hundreds on the pavement along the entire breadth of the west front, the daws continued coming down only at that spot where the first bird had picked up the stick he had dropped. By and by, to my regret, the birds suddenly took alarm at something and rose up, and from that moment not one descended.

For many mornings after, I continued to watch the daws until the nest-building was finished, without witnessing any fresh outbreak of intelligence in the colony: they had once more shaken down into the old inconvenient traditional groove." 
While watching swifts at work I have often noticed how they get in one another's way. In one instance the nest had so far progressed as to assume the form of a curved ledge about one inch in breadth, just large enough to hold a single bird. It sometimes happened that while one bird was at work on the nest its companion would return and instead of waiting for the first swift to vacate the nest, would calmly sit upon that bird; an intrusion which the latter did not appear to resent. The bird on top would then proceed to glue to the nest the material it had brought; but naturally the lower bird would be in the way. Upon one occasion the last-comer glued the feather he had brought on to the tail of his companion under the impression that it was part of the nest; and great must have been his surprise when she flew off with what should have been the latest addition to the nest attached to her tail !

Judged, then, by human standards, birds are in many respects incredibly foolish, and in others marvellously clever. They are neither the one nor the other. The mistake is ours, for birds and other animals should not be regarded from human standpoints. It is precisely because man will persist in making this mistake that so much nonsense has been written about the perfection of the architecture of birds and the extraordinary delicacy of their work. As a matter of fact, a piece of straw bears to a swift much the same relation as a 20-foot bamboo pole does to a man. A human workman who constructed of supple poles, an inch in diameter and six feet in length, a basket the size of a room, would not consider that he was doing fine work. Nor does a swift when it builds its nest. If we take into consideration the size of the bird that makes it, the average nest is a very coarse structure. It, nevertheless, fulfils its function, which is all that Nature requires.

I remember on one occasion hearing the following conversation between a small boy and an old gentleman who were watching a canary eating seed. Said the old gentleman, who was doubtless desirous of improving the 
youthful mind, "Look how wonderfully the bird picks up just one little seed at a time without disturbing the rest. You could not do that with your mouth." "No," replied the boy, "nor could the canary squeeze into its beak a whole half-penny bun, which I can do!" In this case out of the mouth of a babe came words of wisdom. It requires no more skill on the part of a canary to pick out one seed from a heap without disturbing the rest of the seeds, than it does for the baker's boy to pick up a loaf out of his basket without moving the loaves underneath. To understand birds it is necessary to see things as they see them not as we see them. If the average builder were asked to watch a pair of swifts at work and then report on them, he would tell you that they are slow workmen, without method ; that they put themselves to a great deal of unnecessary trouble; that the nest when complete would be condemned by the sanitary inspector as allowing an insufficient number of cubic feet of air per inmate. Show the same builder the nest of a bird that builds in the midst of a thorny thicket so that the builder cannot reach it without severely scratching his hands. $\mathrm{He}$ will think that this is a very clever little bird to thus build its nest in so inaccessible a place. To the bird, however, the place is quite accessible, and the bird has built its nest there because it lives in such thickets. It is no doubt diffcult to cast away preconceived notions, and impossible to see things as birds see them. Nevertheless he who makes the attempt will be rewarded by finding that the actions of birds and beasts suddenly acquire a fresh interest for him. 


\section{XVII.}

\section{"MUSCA DIABOLICA."}

EST these lines should meet the eye of any dipterist, let L me hasten to say that I do not pretend to have discovered any new species, for the creature I am about to describe is only too well-known to Anglo-Indians. Should entomologists cavil at the name and declare that the Indian house-fly is nothing more or less than Musca domesticathe common or garden house-fly, I reply that since there is no satisfactory definition of a species there is nothing to prevent anyone from making a new one out of an old animal, provided there are good reasons for so doing. Do not some dipterists assert that there are two distinct species of house-fly? Why, then, not a third? Consider the great difference in character between English and Indian house-flies; although they are both depraved creatures, the Indian fly-Musca diabolica-is able to work as much iniquity in an hour as an English fly can in a whole day. If one of the latter insects settle upon your nose and you drive it off, it at once betakes itself to some other playground. Not so the Indian fly. It, having once made up its little mind that your nose is a suitable projection whereupon to alight, obstinately persists in settling there no matter how many times you drive him off.

The Italian Ugo Poscolo called the comparatively harmless and innocent house-fly of Europe one of the three miseries of life. His classification would have been somewhat upset by a visit to India.

The Indian fly is the one animal with which I have no sympathy. As I have had occasion to state before, this creature rouses all my worst instincts. Cruelty ceases to be 
obnoxious when practised on one of these pests. You may say that the fly has not the vile smell of the skunk, the sting of the wasp, or the bite of the mosquito. This is true. One can, however, keep out of the way of skunks, wasps have never troubled me, while a punkah will keep off mosquitos. The fly cannot be avoided except by turning night into day. And if everyone made up his mind to do this, I have not the least doubt that, such is the villainy of flies, they would with one accord do likewise. A fly laughs at punkahs; he will settle upon a moving one and smile at you, and then alight upon your face. Flies, like the poor, are always with us. They are more plentiful in the hills than in the plains. They abound in the bazaar and are almost as numerous in the open country. They are equally at home inside the bungalow and outside it. It is impossible to keep them out of the house. It is true that a fly cannot penetrate a chik, nor does he try. He knows a trick worth two of that. He elects to sail majestically into the room on the khidmatgar's back. Once inside the fly loses no time in letting you know it. He does not bite or sting -his torture is more refined than that-he worries. "It is not," wrote Arthur Young, " that they bite, sting, or hurt, but they buzz, tease, and worry; your mouth, eyes, ears, and nose are full of them ; they swarm on every eatablefruit, sugar, milk, everything is attacked by them in such myriads that, if they are not incessantly driven away by a person who has nothing else to do, to eat a meal is impossible." Arthur Young would seem to have camped in India during the hot weather.

You may point out the wonderful structure of the fly. What, for instance, could be more marvellous than his mouth-parts? The fly, like the elephant, has a trunk, but he goes one better than the great pachyderm, for his trunk is telescopic. Yet more, the fly keeps an air-pump in his pharynx. Watch a fly alight upon a piece of sugar. He puts forth his proboscis and-disgusting process-ejects some saliva on to the sugar, thereby melting a minute por- 
tion. He next, by means of powerful muscles, suddenly expands his pharynx and creates a vacuum, into which the liquified sugar rushes. The pharynx then closes, forcing the food into the gullet.

My admiration at this wonderful apparatus is more than outweighed by the knowledge that the fly uses it upon me whenever he has the chance. Then, again, you may call attention to the structure of the fly's foot, the base of which is provided with a pad or sucker, by means of which he is able to walk quite comfortably on the ceiling. This is undoubtedly a great gymnastic feat; but, as before, the fly employs his talents to annoy poor human beings. He uses his suckers to walk over what would otherwise be inaccessible portions of the human frame.

The visual organ of the fly is an extraordinary structure. The average fly possesses some 4,000 eyes, or rather each of his eyes is composed of 2,000 facets. It is a disputed point as to whether each of these produces in the brain a separate image, or the whole 2,000 produce but one image. If the former is the case the reader must not imagine that when a fly looks at a spider he sees 4,000 of those animals. Man is blessed with two eyes; nevertheless, under ordinary circumstances, he only sees an object once over. It is, however, quite possible that a fly, after many draughts at your whisky, may see 4,000 objects where only one exists. This should be enough to make him a teetotaller. But, alas ! so wicked a creature is the fly that no object-lesson would ever reform him.

Even as the anatomy of the fly is wonderful so is his nature black. Prolonged observation has convinced me that the fly has no single redeeming feature in his character. $\mathrm{He}$ is not industrious like the ant or the bee. Flies literally fritter away their time. From the inside of a mosquito net I have watched them by the hour. They do nothing but fly aimlessly about, occasionally knocking up against one another in the most absurd way. Out of doors the fly is still more ridiculous. "It is impossible," writes Hudson 
of the flies seen on the Downs, "to overlook creatures that conduct themselves in such a wildly eccentric manner. One big yellow fly like a honey-bee comes directly at you with a loud hostile hum or buzz, hovers for a few moments, dashes away in a straight line, turns off at a tangent, and, rushing back again, proceeds with extraordinary velocity to describe curves and circles, parallel lines, angles, and other geometric figures, in the air ; and finally drops down within a few inches of you, to remain motionless as a fly carved out on a yellow pebble until the impulse sends him off again. What his motives are, what it all means, we are unable to guess; we can only conclude in our ignorance, judging from appearances, that he is mad; that in fact, the proverbial March hare is a pre-eminently sane, sensible creature in comparison. Somewhat of this lightheadedness is, I imagine, seen in most of the flies, from the burliest blue-bottle to the small gilded variety. What would it be, I wonder, if these minute creatures grew to the size of ducks and geese? Our whole time would be spent in watching their amazing, meaningless antics; nothing else would be talked or even thought about in the world. In the end we should become strictly nocturnal in order to be out of their way, or we should ourselves go mad in their company."

Nor has a fly any power of endurance. This I discovered by accident. One of these gentry went to sleep inside my mosquito net, and, rising with the lark, he commenced to tease me. I opened part of the curtains and endeavoured to chase him out. In vain; the fly simply laughed at me. The iniquities of this brute had been great. I saw that there was nothing left but war to the death. I closed the curtains, took up a strategic position in the middle of the bed, pulled at the part of the curtains on which the fly had settled. He at once made for the opposite side. Before he had time to reach it this was violently agitated by me; not being able to settle on territory in the throes of an earthquake the fly made for another portion of the curtains. 
These underwent similar contortions, so the bewildered fly flew about seeking in vain a piece of terra firma, whereon he might rest the soles of his feet. The question was who would tire first, the fly or myself. The victory fell to me, and it was gained far more rapidly than I had expected. In less than three minutes the fly was utterly exhausted. I caught him, crushed him, and cast him forth.

Not only are flies absolutely useless, but they are positively injurious. They are the carriers of disease-the spread of enteric fever is another sin which is now laid to their charge. I often wonder they are not systematically caught and used as manure. Why does not the Agricultural Department take up the matter, and thus at the same time lessen disease and render the soil more fertile?

The fly lays its eggs in the filthiest of places; a manure heap is in its opinion an eminently desirable site. The egg hatches out as a maggot-a creature, to say the least of it, not attractive. It possesses neither eyes nor feet; it does not need them since it is born and lives in the midst of its food. After a time the maggot enters into the pupal state. Its skin hardens just as that of a caterpillar does. Inside the hardened integument the maggot literally melts; and from the semi-liquid mass the tissues of the fly are formed. The insect then emerges from his case to lead his iniquitous life. Besides man, with his fly-flapper, flies have many enemies. Lizards, spiders, frogs, toads, and a host of other animals eagerly devour them. Most insidious of all are its plant foes. Two little fungi, termed Empusa and Entomophthora, are parasitic on flies. Most of us have seen dead flies stuck on to a window pane with a kind of halo round them. These are flies which have been destroyed by one or other of these vegetable moulds. An infinitesimal spore is taken into the body of the fly and from that moment the insect is doomed. The spore grows rapidly and divides into a number of cells, until it has become a much-branched tube which ramifies throughout the body of the fly, absorbing its tissues. The growth of this para- 
site so weakens the luckless fly that it is eventually unable to exert the force requisite to detach the pads of its feet from the window-pane, or other object upon which it may have happened to settle. So it must, perforce, remain glued to the spot while the fungus sucks up its life blood. After a time the mould throws out the reproductive organs, which stand out from the body of the fly like a number of white hairs : it is these which produce the halo-like appearance round the corpse of the fly. By the time this has happened all the inside of the insect has been eaten up. Thus you behold your former tormentor transformed into a dry, lifeless, shrivelled-up mass-quantum mutatus ab illo? 


\section{XVIII.}

\section{HOBBLEDEHOYS.}

DURING the monsoon in the Himalayas there comes at rare intervals a perfect afternoon-a superb hundred minutes before twilight, when the rain has ceased and the slanting rays of the sun have lost their noonday fierceness ; when the fragrant verdure of grass and foliage is such that the scene might be Scotland and the time early June; when the air is at that ideal temperature-alas! so seldom met with-which is purely pleasurable to the senses of one reposing in the open. It was on such a day that I chanced to come upon one of those little burns so few and far between in the arid Himalayas. The stream was but a gentle trickle of water, yet its soft splash was soothing to the ear, so I sat me down beside one of the tiny shallow pools through which the rivulet passed in its downward course.

Every piece of water, larger than a mere puddle, contains a little world of living beings, and even the ephemeral puddle is not without its vital organisms. The area of the pool by which I rested was less than four square yards, yet it displayed quite a considerable aquatic population, composed chiefly of water-insects and tadpoles. The former frolicked about in the pellucid liquid, heedless of the frog larvæ that were nibbling at the soft green algæ which formed the velvet carpet of the miniature lake, for tadpoles are vegetarians until they lose the tail ; with the disappearance of this appendage they put away childish things and become beasts of prey. There must have been forty or fifty tadpoles in that small area. They were in all stages of development. Some were all head and tail. In others tiny hind limbs had budded forth. A few had attained the 
dignity of all four legs, but these were as yet inconspicuous beside the great tail. In one or two the caudal appendage had already begun to shrink, so that they were neither tadpole nor frog-veritable nondescripts, hobbledehoys.

Thinking that a little excitement and exercise would be good for their constitutions, I amused myself by trying to catch the quaint little creatures, who were there before my very eyes undergoing evolution, for each and every one, although he knew it not, was busily engaged in climbing up his own genealogical tree. One might as reasonably hope to catch the moon as to seize one of the pure tadpoles, who have not yet developed limbs. These, when disturbed, dash about in the water at a pace which would put an East Indian Railway train to shame. While going at top speed they twist and turn in such a manner as would bring tears to the eye of the polo pony. The hobbledehoys were, however, comparatively easy to catch. The advent of the legs entails a great diminution in the natatory power of the tail, and when first formed the former are too weak to be of much service in either swimming or walking.

Holding one of these frightened youngsters in the hand, one's thoughts naturally turn to Nature's hobbledehoys. What are these incipient frogs but counterparts of the ungainly human being, aged fourteen or fifteen, all legs and arms, with a voice which a crow would be ashamed to own? All animals pass through a similar ungainly stage in the course of their life history. There are, however, these differences between animal and animal. In some the change, the transformation, is more marked than in others. Some undergo the transition in public; others in private. The development of the frog presents an extreme case. It emerges from the egg as a limbless fish, and ends life as a quadruped capable of living for a time at least on terra firma. So complete is the change, that, in scientific parlance, the frog undergoes metamorphosis during its progress from youth to age. Why should animals be obliged to pass through this awkward stage of hobbledehoyism? 
To answer this question one must, perforce, wax philosophical. Nature knows one way only of developing an organism. It has to tread the path traversed by its ancestors. Its development is a recapitulation, more or less complete, of the evolutionary stages through which its forefathers have passed. In a few short weeks the developing animal covers ground over which its progenitors required hundreds of thousands of years to tread. The fierceness of the struggle for existence has forced on Nature the necessity of making development as rapid as possible. The life-history of every animal falls into two periods. In the first the organism is shielded from the universal struggle or, at any rate, takes no part in it; in the second, it has to fight its way or perish. It is obviously for the benefit of the individual that the former period should be as long as possible, for the more highly developed an animal be at birth the better account of itself will it give in the struggle for existence. On the other hand, it is to the advantage of the species that this period be short, for, if the eggs develop outside the mother, the more rapidly they give rise to young animals the less will be their risk of destruction. If the young develop within the mother, the shorter the embryonic period the greater the number of successive offspring the female can produce in her lifetime.

Hence a balance has to be struck. The result is a short embryonic period, but a highly developed animal at birth, an animal in most cases able to maintain itself. This organism, however, although able to take care of itself, is often very far from exactly resembling its parent. This will come later. The first necessity is the rapid development of an individual capable of fending for itself. If the creature resemble the parent, so much the better'; if it do not, it will have to undergo the transition while earning its living and thus pass through a stage of hobbledehoyism. The tadpole can be evolved in a few hours from frog's spawn; but the making of an adult frog requires several weeks; and if the eggs were exposed defenceless all this 
time, poor froggy would stand little chance of ever being born; so the egg hatches out as a tadpole. This creature is what zoologists term a larva. A larva is a device of Nature, whereby she is enabled to make an embryo take care of itself. The tadpole is nothing but an embryo, which has learned to look after itself-a precocious baby prepared to defy the world.

It is thus clear that whenever an animal has to shift for itself before it has had time to attain the adult form it must pass through the hobbledehoy stage. The young of herbivorous animals form an interesting case in point. Whatever people may say of the prettiness of lambs, these creatures are in reality far from being beautiful, being sadly out of proportion; and the same applies to foals, goats, calves, etc. All these young animals have one marked peculiarity : their legs are too large to be in proportion with the rest of the body. These animals are, so to speak, all legs. Contrast the young tiger or the kitten. These latter are small editions of their parents, and are born with limbs proportionate to the rest of the body. The explanation of this difference is simple. Herbivora are timid, defenceless creatures; fleetness is their one safeguard. In this respect a female with young is heavily handicapped. Her speed cannot fail to be checked by the extra weight she carries. It is therefore most important to the welfare of the species that the young be born as early as possible; but if they were born like kittens unable to walk, so that the mother had to carry them in her mouth when she desired to move them, both she and they would quickly fall victims to some beast of prey. It is therefore essential, not only that the young of herbivora should be born early, but that they should be able to run from the moment of birth. Hence the seemingly absurdly large legs and the hobbledehoyish appearance of the young animals. The speed at which young calves can run is astounding. In India one has ample opportunities of testing this. In every mofussil town it is almost impossible to go for a ride in the evening 
without meeting the home-going cattle. The thick-headed cowherd has not the least control over them; they spread themselves all over the road, and promptly turn tail and run when they see a horseman. Quite a young calf will, with seeming ease, keep ahead of a horse going at the rate of eight miles an hour.

With carnivores the case is different. It is indeed important that they should be born before they are very large, more important even than in the case of the herbivora, since the latter find their food growing round about them while the former have to hunt it. On the other hand, there is no necessity for young carnivora to be able to run when first born, since they have but few enemies, and are hidden away safely in a den. Thus young carnivores are born with all their limbs in proportion, and although blind, and otherwise not so highly developed as young herbivores, show a greater resemblance to the parents. A similar difference is noticeable between the young of birds, which build nests, and those which do not. Take, for instance, two wellknown Indian birds : the myna and the common fowl. The myna never appears in public in a hobbledehoy stage. When first hatched it is a ghastly sight, blind and naked, all beak and crop, and altogether incapable of looking after itself. It is, however, safe in the nest and well looked after by the fond parents. Soon the feathers appear, it quickly attains the form of the adult, and becomes generally presentable, and then, and not till then, it leaves the nest. Thus the young myna is nursed in the lap of luxury; it has no work to do as a youngster, and repays its parents for the care they have lavished upon it by flying out of the nest and strutting about "with an elegant tripping gait, like that of a neatly built ballet girl, alert and brave, in bright yellow boots." But for its size and its feeble flight, it is indistinguishable from its parents. The young bird is very proud of being able to fly, and executes every motion most correctly, like a schoolgirl at her first dance when she silently counts the steps, trembling lest she should make a 
literal faux pas. It is most amusing to watch the efforts of a young myna as it tries to catch a locust. The chase is invariably a long one, and, as likely as not, the insect escapes. Thus the myna makes its débît, looking smart and sprightly as though it had just come out of the proverbial band-hox; there is nothing of the hobbledehoy about the youngster. What is still more wonderful, the myna seems never to grow old. Who has ever seen a hoary-looking, worn-out myna? The bird may well be envied by human beings, for it seems to have discovered the secret, if not of perpetual youth, at any rate of permanent good-looks.

How different is the lot of the chicken. He has no nest to protect him, so that were he to hatch out of the egg in a state similar to that of the myna he would not survive an hour. He is obliged to a great extent to look after himself from the moment he is born, so he emerges from the egg covered with down, able to see and run about, nevertheless very unlike either of his parents. All the while that his feathers and comb are growing he is earning his living, and so has to appear in public as a hobbledehoy-half downy chick and half feathery fowl. In this condition he may be seen outside any dâk bungalow, and is neither beautiful to the eyes nor tender to the teeth. 


\section{XIX.}

\section{A WINTER VISITOR.}

BIRDS are admirably equipped for travel. Their mode $\mathrm{B}$ of progression is one which man has for centuries tried in vain to imitate. No barrier deters them. They laugh at high mountains and mock the ocean. Birds require no baggage. Their progress is hindered by no impedimenta. They are not dependent on inns, hotels, or dâk bungalows. They, in short, are able to go where they list. Under such circumstances, it is not surprising that many birds are great travellers. It is rather a matter for wonder that all of them do not take full advantage of the migratory powers with which Nature has endowed them. The globe-trotting birds do not move about aimlessly from place to place with the object of seeing the world and killing time, as is the way of many human travellers. There is method in the wanderings of birds. Their journeys are periodic, and are dictated by necessity rather than inclination. We, who live in the twentieth century, find it hard to realise what the food problem means for less favoured beings. It matters not to us if we live in a land flowing with milk and honey or in a little island so thickly populated that the soil cannot produce sufficient food in a year to feed the inhabitants for three months. Food is brought to that island from all parts of the world in mighty ships. With birds things are different; so even was it with our forefathers. The diligent student of English history must have noticed how our mediæval kings were constantly on the move. The court was never held for any length of time in one place. The king and his large following did not take long to devour all the good things of one locality, and then must needs move 
on to another. In those days there were no railways, and the roads were not such as to allow the carriage of large quantities of supplies. The mountain would not come to Mohammed, so the prophet must perforce go to the mountain. So it is with birds. When the food-supply of one tract of country is exhausted, they must starve or move on.

This is the secret of the phenomenon of migration. There are doubtless other causes contributing to the migratory instinct, such as preference for a balmier climate. But assuredly it was the question of food-supply that gave rise to the habit of migration which has now become an unalterable instinct with some birds. India is the favourite winter resort of many animals. From October to April we are invaded by a huge army of globe-trotters of all sorts and conditions. The common or grey quail is one of the best known of our bird-visitors. This pretty little bird rejoices in the name of Coturnix communis. In early October it leaves its happy hunting grounds in Central Asia and Europe, and betakes itself to a serener clime. Many of these birds select India as their winter resort, and certainly they might go farther and fare worse, for from October until April the climate of northern India is not far from perfect. There is, too, food in abundance. Thus quails, who know upon which side the bread is buttered, come to visit India in myriads. After having lived on the fat of the land for six months, these bright little game birds bid us goodbye and go. They leave the heat of the plains with the same regularity as a Viceroy or Lieutenant-Governor. Shaking the dust of India off their wings, they betake themselves to their northern haunts. Just as no European in his senses remains in the stifling plains if he can avoid doing it, so not a single quail (I speak of the grey quail), unless compelled by necessity, spends a hot weather in India. A few have to endure this torture. All cannot manage to get away. It is not press of work that detains these unhappy birds, but the sportsman's lead. A great number of quails receive slight "gunshot wounds," which, although not fatal, render them 
too weak to perform the long journey over the hills; such birds must, therefore, grill in the plains, while their more fortunate companions are disporting themselves in northern latitudes. There are some who maintain that many quail remain in India during the summer from choice. For instance, if they happen to come upon a place where food is particularly abundant, they refuse to leave it when the time for migration comes. This I do not believe. The migratory instinct must be so deeply ingrained in the birds that nothing short of necessity would prevent their obedience to its promptings.

Much has been said of the wonderful way in which the quails migrate each year on almost the corresponding day. As regularly as clock-work they appear in Kumaun in early October on their way south, and again in April on their northward journey. On reflection, however, their regularity of appearance is not surprising. There must be some stimulus which sets the migratory instinct in motion, which suddenly impels the bird to go on its travels. What this stimulus is we cannot say for certain. Temperature probably has something to do with it.

Migration takes place during the night. Throughout the day the birds rest in a field of ripe crops, which provides them with food, shade, and cover. The long journey which the quail takes must occupy several days or rather nights, and if he set out at a time when no food was obtainable en route, at a time when the fields were all bare, he would almost certainly perish before arriving at his destination. Thus, natural selection tends to fix the period of migration within narrow limits. But, it may be objected, this does not explain how it is that the quail always knows when the crops are ripe, and makes the journey at this period. I do not think that the quail knows that a crop is ripe when he is thousands of miles away. Blind instinct impels him to set out on his travels. After he has flown a long distance he looks out for a halting place and selects the first field of ripe crops that meets his eye. Natural 
selection has caused him to commence his journey at the time that the crops on his way are ripening, and chance determines the field in which he halts for the day.

It is well-known to sportsmen in the Himalayas that there are good and bad years for quail. The difference between a good and a bad year does not lie, I think, in the greater or lesser quantities of migrating birds. I say this with all due respect to Messrs. Hume and Marshall, who write : "in some years many more quail, probably many millions more, visit India than in others." No doubt the numbers of quail which visit us do vary considerably from year to year. This, however, does not, in my opinion, account for the difference between a good and bad year in the Himalayas. If the crops of any area happen to ripen at the moment of maximum migration, great numbers of the passing birds alight in the fields; if the ripening of the crop does not coincide with the time of the chief wave of migration, very few birds come into the fields. It may be urged that this explanation will, doubtless, account for the number of birds seen in the hills, but what about the variations of the plains? This question may best be answered by quoting some remarks made by Mr. Davidson. : "If they (the quails) find sufficient provision in Upper India and Gujarat, the majority stay there, and comparatively few are seen in the south. While in years like 1878 (when the crops were deficient in the north) immense numbers come south." The quail is a sensible bird. He knows when he is well off. When he comes to a place where food is abundant, he refuses to budge.

I have said so much about migration that there remains but little space to be devoted to our migrant-the grey quail. This does not matter, for the quail is one of the best known of our Indian birds. Every possessor of a gun knows its habits when free, and most housewives have ample opportunity of studying its doings in captivity. Quail feed early and late in the day, and enjoy a mid-day siesta. Any kind of grain and most of the smaller insects form 
their food. Quail have good healthy appetites. Three thousand five hundred seeds of chickweed were once found in the crop of a single quail in England. The males are most pugilistically inclined, but it appears to be etiquette not to fight in.the dark, hence light is generally shut off from quaileries. The sporting Mussulman takes as much pride in his fighting quail as our worthy ancestors used in their game cocks. The quail does not, as a rule, breed in India ; the eggs, however, must be laid very soon after the birds have arrived at their northern residence. The nest is a mere hole scratched in the ground. Those birds which are compelled to spend the hot weather in India usually breed in April, laying six or seven eggs.

Quail used to be abundant in England, arriving in May and going south in October. This smart little bird is alas! like so many others, becoming scarce at home. It would seem that its visits to our little island will soon be a thing of the past. 


\section{XX. \\ A TWILIGHT IDYLL.}

THE sun is sinking behind the western hills. The stillness of twilight is fast settling over the Himalayas. Before me flows a mountain stream, over the rippling water of which a number of redstarts are disporting themselves. Beautiful little birds are these. Within a few feet of me, standing upon a projecting rock and jauntily spreading his tail, is one of the plumbeous species, a bird which Jerdon has aptly named the water-robin. Very like a robin he looks. His body is dusky indigo blue, while his tail and abdomen are ferruginous. Seen from a little distance the water-robin does not look particularly interesting when at rest. But, hey presto! he has turned into a flash of red! He has taken to his wings and flight has transfigured him.

Water-robins feed upon the flies and midges which occur in such numbers over the surface of running water, and this particular one and his companions are busily engaged in securing their evening meal-a task which entails a series of excursions into the air, a succession of short rapid flights like those performed by the king-crow. Sometimes the bird returns to the boulder from whence it started; more often it alights upon another stone. The flights are never long; their sweep rarely exceeds four yards.

A little beyond a similar occupation, is a far more handsome bird, the white-capped redstart. His plumage is black, relieved by a patch, as white as snow, on his head; while the tail, abdomen and rump are red-a more brilliant red than 
that of his smaller relative. His body and tail are longer, and he is more slimly built. He is the dandy of the rivulet. His mate has now joined him ; and they leave for a few minutes their chase after flies and aquatic insects to play a game of bide-and-seek among the boulders on the river's edge. They flutter about merrily, kissing one another when they chance to meet. Suddenly one flies away with a cheery twitter, while the other returns to his hunting, which he seems to pursue with renewed vigour.

Meanwhile the various members of the plumbeous species are catching their liliputian prey with unflagging energy. On an average they make two, or three, little flights in a minute. A few seconds intervene between each, during which the birds flirt their tails. Now and again, apparently from sheer exuberance of spirits, one of them indulges in a different form of flight. He bursts forth into song, emitting a bright twittering note-shrill but not unpleasant to the ear. While singing the bird flies up the stream for about twenty yards, whirls round, and returns. His song seems to be infectious, for it is usually taken up by one or more of his companions.

Deeper and deeper sinks the sun. No longer are the western slopes of the highest peaks tinted red. A bulbul alights on one of the bushes on the opposite bank of the stream. He is joined by his spouse. They twitter to one another for a little, and then fly away in company.

A wagtail now comes to the water's edge. He is fleet of foot, and runs about the stones and boulders, which are lapped by the waters of the river. He hopes to find stranded there a few aquatic insects.

Twilight is fast becoming night. The stars have already begun to peep. A bat-herald of the approaching nightnow joins the redstarts in the pursuit of the unfortunate insect. Unlike the birds, the mammal would seem to fear the water, for he does not venture over it. His flight resembles the beat of a drunken sentinel, for he careers in a wavering course up and down fifteen or twenty yards of 
the river bank, on the very edge of the water, and but an inch or two above it. Backwards and forwards he takes his silent flight, neither pausing nor resting.

As the gloom deepens the colours of the redstarts seem gradually to fade away: so that it would be difficult to distinguish between the birds and the bat, but for the fact that the latter never rises to the height of a yard above the surface of the water.

It has for some time been too dark for the human eye to distinguish such minute objects as flies, yet the activity of the redstarts shows no signs of abatement. Their numbers certainly seem to have diminished; but this may not be the case. In the fading light none but the nearest can be seen.

A huge owl glides overhead, and settles on the bare branch of a tree. This he does in grim silence. Once settled, he remains moody and motionless, looking down upon the water, uttering not a sound. Surely now the redstarts will retire for the night? The bulbuls and the wagtail have long since disappeared. But no, the diligent little birds still dash about from boulder to boulder, evidently anxious not to lose a moment of the precious daylight.

All the redstarts have now flown away, save one-a water-robin. He settles upon a stone, and for the space of three minutes gazes at the running water which surrounds him. His air is pensive. He still flirts his tail, but in a slow and gentle manner. "Alas!" he seems to say, "it has grown too dark; I, also, must go to rest." Then he flies away, leaving the stream to the denizens of the night. 


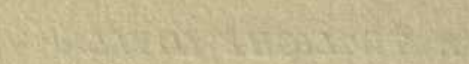

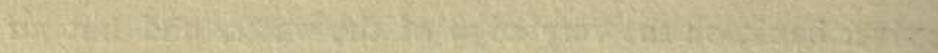
46.

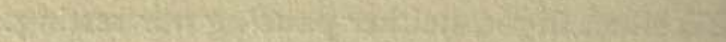

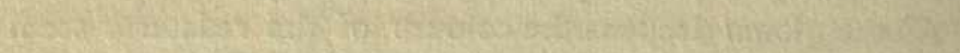

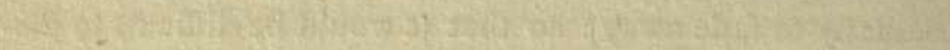

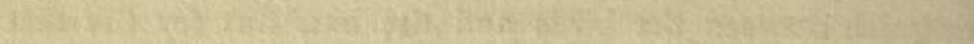

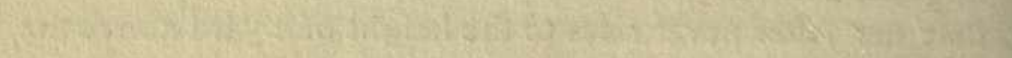

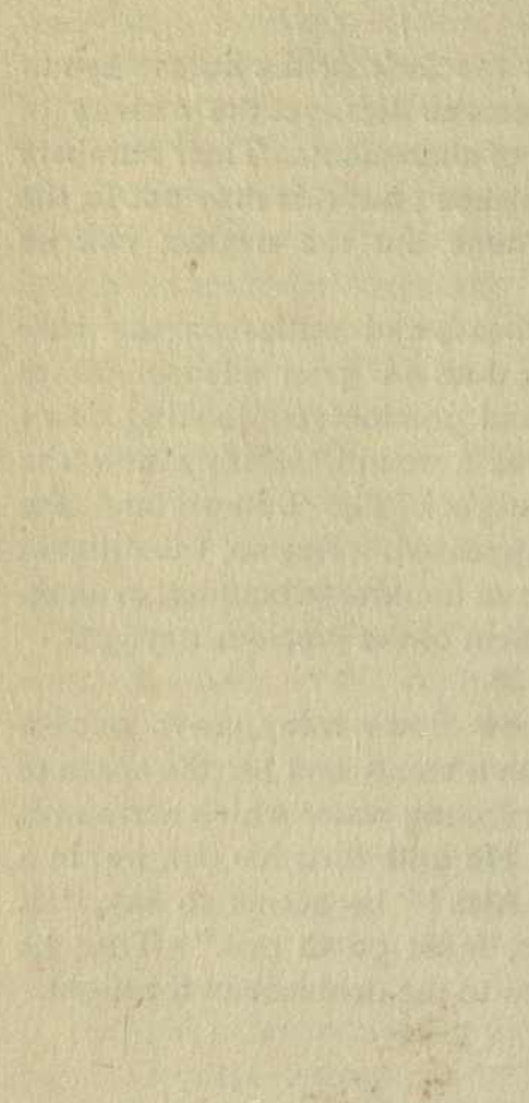

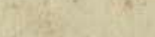



(i):

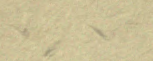

B.

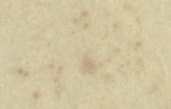

thi 



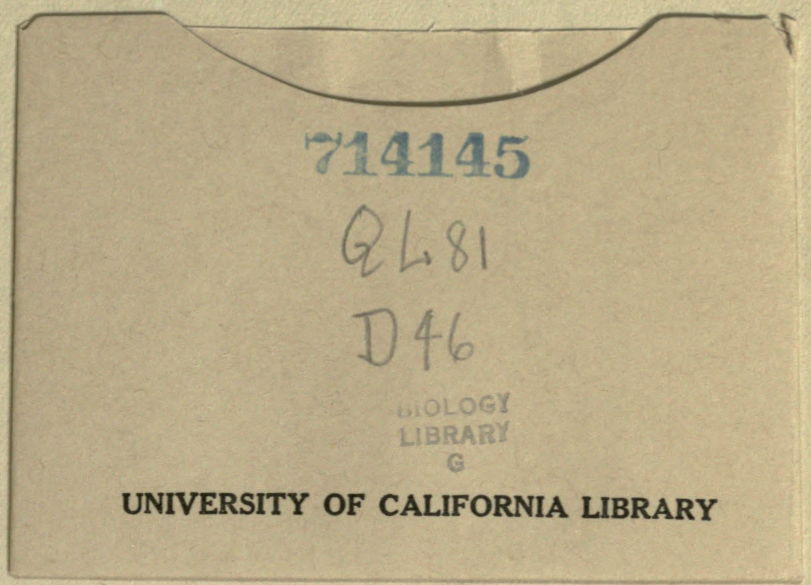


